\title{
Imagination, Cultivation, Creation: An exploration of a customized acting process and personalization of Theresa Rebeck's "Seminar"
}

\author{
Brianne N. Taylor
}

Follow this and additional works at: https://researchrepository.wvu.edu/etd

\section{Recommended Citation}

Taylor, Brianne N., "Imagination, Cultivation, Creation: An exploration of a customized acting process and personalization of Theresa Rebeck's "Seminar"'" (2015). Graduate Theses, Dissertations, and Problem Reports. 6780.

https://researchrepository.wvu.edu/etd/6780

This Thesis is protected by copyright and/or related rights. It has been brought to you by the The Research Repository @ WVU with permission from the rights-holder(s). You are free to use this Thesis in any way that is permitted by the copyright and related rights legislation that applies to your use. For other uses you must obtain permission from the rights-holder(s) directly, unless additional rights are indicated by a Creative Commons license in the record and/ or on the work itself. This Thesis has been accepted for inclusion in WVU Graduate Theses, Dissertations, and Problem Reports collection by an authorized administrator of The Research Repository @ WVU. For more information, please contact researchrepository@mail.wvu.edu. 


\title{
Imagination, Cultivation, Creation: \\ An exploration of a customized acting process and personalization of Theresa Rebeck's "Seminar"
}

\author{
Brianne N. Taylor
}

\author{
Thesis submitted \\ to the College of Creative Arts \\ at West Virginia University \\ in partial fulfillment of the requirements for the degree of \\ Master of Fine Arts \\ in \\ Acting \\ Lee Blair, M.F.A., Chair \\ Alan McEwen, M.F.A. \\ Jessica Morgan Bishop, M.F.A.
}

School of Theatre \& Dance

Morgantown, West Virginia

2015

Keywords: Acting, Seminar, Theresa Rebeck, Meisner, Free Associative Journaling 


\section{ABSTRACT \\ Imagination, Cultivation, Creation: \\ An exploration of a customized acting process and personalization \\ of Theresa Rebeck's "Seminar"}

\section{Brianne Taylor}

“... all anyone wants anymore are memoirs. And I'm not saying, I think it's an interesting form, I'm as curious about the inside of my own brain as anyone but please!"

-Douglas, Seminar

The following document delineates the process of undertaking my thesis role of Kate from Theresa Rebeck's Seminar for West Virginia University's fall production in the Gladys Davis Theatre. The process will examine the themes and fervors of the play as contrived through the ideals and desires of a young writer in the modern fiction world. It will illustrate the research I have collected from the vast world of fiction literature (classical and contemporary) and the process of creating this fiction, as well as visual art that inspired the molding of Kate's perspective. The usage of free associative journaling and action rooted in Sanford Meisner's technique will serve as the base of the rehearsal process. Assessments of discoveries made and audience reaction through the run of the show will be included, as well as a sincere evaluation of the progress made in my venture. 


\section{ACKNOWLEDGMENTS}

As a graduate student of a program that includes a teaching assistantship, I would like all of my teachers in my life to know: I get it now. I understand the effort you exerted, the words of wisdom you gave me, the frustration you had when I was lacking in effort, your eagerness to make me better, and I thank you for it. I hope that one day I may be able to pass along a bit of the wisdom, determination, encouragement, tenderness, work ethic and passion with which you taught me. Without the wise words of Julie Gray McCreight, Roxie Brookman, Allyson \& Roger Moon, Nancy Pontius, Susan Mai, Jim \& Lindy Bartruff, Amanda Dura, Theresa Mitchell, Jim Ryan, RJ Nestor, Lee Blair, Jerry McGonigle, Jessica Bishop, Laura Hitt, and Roger Smart, I would not have been able to fill this role with integrity.

In the midst of all these great teachers, I met a really great man who helped me even more along my way. Without him, the house would be more cluttered with books and journals, dishes would never be clean, and meals would consist mostly of popcorn. Joshua Taylor, you are there to celebrate with me when the performances are good and there to put me back together when the process is bad. You keep me sane and happy. I couldn't ask for a better partner.

But before all of these wonderful people in my life came along, I was surrounded by a far more constructive group: my family. Mom and Dad, you may not always have understood what I was going through, but you always had rallying words of encouragement and you always supported my decision to pursue my passion. There has never been another option for me and I am able to see this clearly because of the values in life you have instilled in me.

Grandma and Grandpa, you are my biggest fans! You are often times more excited about my work than I am and every curtain call I feel your presence - I know you're out there giving me a standing ovation.

My dear, dear siblings have probably had the biggest impact on my education over the last twelve years. Jacob, Renee, and Barrett-thanks to you, I am pretty sure it's safe to say l've 'won' at least $95 \%$ of all games and activities in the classroom, and I am exceptionally good at stage combat...

"Nothing of me is original. I am the combined effort of everyone l've ever known." -Chuck Palahniuk 


\section{TABLE OF CONTENTS}

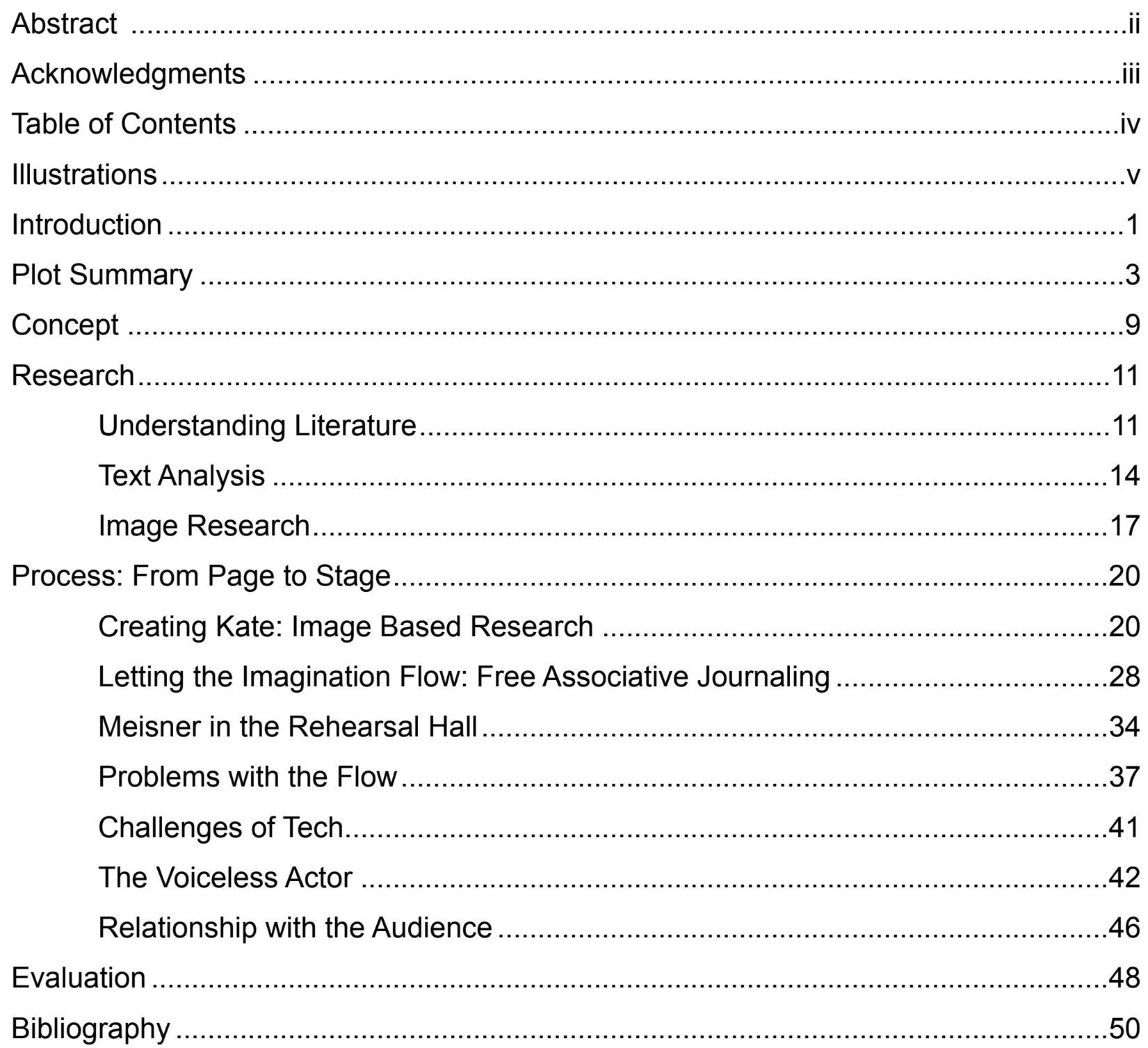




\section{ILLUSTRATIONS}

Fig. 1. Reuters, Gregory Cherin, and Bennington College. A view of Bennington College in Bennington, VA, is seen in this handout photo taken in 2007. Digital image. Reuters.com. N.p., 30 Oct. 2008. Web. 22 Aug. 2014. <http://www.reuters.com/ article/2008/10/30/us-financial-colleges-idUSTRE49T02E20081030>.

Fig. 2. Courtesy of the MacDowell Colony. One of the several artist studios at the MacDowell Colony. Digital image. Ricardo Lorenz. Word Press, n.d. Web. 22 Aug. 2014. <http://www.ricardolorenz.com/?p=579>.

Fig. 3. Courtesy of the MacDowell Colony. Colony Hall at the MacDowell Colony, Peterborough, N.H. Digital image. Encyclopedia Britannica. N.p., n.d. Web. 22 Aug. 2014. <http://www.britannica.com/EBchecked/media/95165/Colony-Hall-atthe-MacDowell-Colony-Peterborough- $\mathrm{NH}>$.

Fig.4. Brink, Brian Vanden. IUD Writer's Colony in Saratoga Springs, NY. Digital image. In Transit. New York Times, 31 Aug. 2011. Web. 22 Aug. 2014. <http:// intransit.blogs.nytimes.com/2011/08/31/a-chance-to-peek-inside-yaddo/?_r=0>.

Fig. 5. Spencer, Krispen. Rainbow. 2014. Acrylic Painting. Ugallery.com. 19 Aug. 2014. Web.

Fig. 6. Horvath, Bator. diamonds. Composed December 30, 2008. Private collection. flickr.com. Web. August 2014.

Fig. 7. Monks, Alyssa. Tell. 2011. Oil on panel. Tonic. 2011. Oil on panel. Allow. 2012. Oil on panel. The Jealous Curator. Web. August 2014.

Flg. 8. Jones, Conrad Crispin. Smok'in Ivy. 2013. Painting. Spain. Saatchi Art. Web. August 2014

Fig. 9. Jover, Loui. guinevere. n.d. Ink on vintage book pages. Australia. Saatchi Art. Web. August 2014.

Fig. 10. Oxer, William. The Wish. n.d. Acrylic painting. United Kingdom. Saatchi Art. Web. August 2014.

Fig. 11. Jover, Loui. tango. n.d. Ink on vintage book pages. Australia. Saatchi Art. Web. August 2014.

Fig. 12. View of the Larynx from above, showing the connection of the Arytenoid Cart. to the back of the vocal folds. "Voice Science Talk: Paresis". New Voice, New Career. newvoicenewcareer.blogspot.com. 4 March 2011. Web. 


\section{INTRODUCTION}

There was a lot of trepidation in the beginning of this process, a fear to even pick up the script. I knew I wanted the end result to be good, to be great, to be bewitching, to speak volumes, to be something fantastic-I simply had forgotten how to get there. It was a bit like that point in your childhood when you wanted to pop a wheelie on your bike with every fiber in your being, but you had forgotten how to even balance. You would stand there, hopping up, trying to put both feet on the pedals-only to have to stick that leg back out to catch yourself from falling. You had forgotten that in order to keep your balance, you have to get moving.

I picked up my script several times in the three months prior to rehearsal only to flip throughout the pages rapidly and set it back down almost immediately. It was only more daunting once I had gone through and highlighted my lines; now a blur of yellow was all I saw while flipping through the script. I even bought a new one so I could try to work without the highlighter hindering my concentration. I began reading authors referenced in the script so I would not have to work with Rebeck's words just yet. Finally, in my research, I came across this quote:

"Art, especially the stage, is an area where it is impossible to walk without stumbling. There are in store for you many unsuccessful days and whole unsuccessful seasons, there will be great misunderstandings and deep disappointments...you must be prepared for all this, accept it and nevertheless, stubbornly, frantically follow your own way..."

- Chekhov, in a letter to his wife ${ }^{1}$

I wish I could say that did the trick, that I instantly picked up my script and connected with the understanding of my character immediately, that her words flowed out of me with clarity and specificity; but it did not happen that way. I spent another couple weeks shirking the script before I re-read this quote in my journal and decided to face my fears.

My fears were not superficial; rather, they were solidified once I picked up the script. Kate is an incredibly complex character. She demonstrates the most growth through the span of the play and yet manages to show the least action of growth

${ }^{1}$ qtd. in Sher, p. 231 
physically on stage. It all happens between scenes. This meant ten to fifteen seconds of mental prep before jumping into a new Kate-definitely with some sort of costume change each time and possibly some scenery or prop handoffs. This would require a substantial amount of mental dexterity for the actor and the character, in addition to the physical demands of vocal work (quantity and emotional intensity) demanded by this role.

There were multiple ups and downs along this journey. Several events set me back that I either instigated, or the fates decided to challenge me with: moments of procrastination surfaced during line memorization and the journaling process, comfort with trusting my cast mates became an issue at times, and the loss of my voice in the days before opening shook me physically and mentally. The end result mattered still, but it was not going to drive me. The process became the more valued objective. And as those who know me can attest, I did, indeed, stubbornly and frantically follow my own way. 


\section{PLOT SUMMARY}

Seminar is a quick, modern play recently produced on Broadway. Running only an hour and a half without intermission, it is an easily enjoyed evening of theatre for the audience. The script opens in New York City. The time is now, in the fall, spanning approximately a fourteen-week period in which four young writers are engaged in a private seminar with an internationally recognized literary guru. It sounds simple, it sounds basic, and it even sounds a little mundane for those of us who are not immersed in this intellectual world. Theresa Rebeck's writing is far from uneventful and it is even further from being un-relatable. She manages to tackle the internal desires of every individual of the human race in an engaging, enticing, and non-cliche way.

The play opens mid-conversation among four young, aspiring writers. They have gathered at Kate's upscale New York City apartment (to be clear, it is owned by her parents, she is only living there temporarily) to meet-and-greet one another before starting their lessons with the infamous Leonard. Douglas is immediately categorized as the uppity snob as he drones on and on about his experiences in the writers' colonies of Yaddo and MacDowell in a vocabulary that is a bit too ethereal for the rest of society. Kate is exploited as a rich little snob once it is revealed her family pays a tiny sum for their apartment with a view of the river; everyone immediately assumes she bought her way into the seminar. Martin and Kate's friendship beginning in high school is made known to Izzy and Douglas; as well as a tension that could mean a little more than friendship, at least for Kate. Martin exhibits himself to be of a significantly lower financial status, intelligent, intolerant of people who show off (even though he does it himself); and demonstrates a possession of the downfall of most men: swooning for sexy women based solely on physical attributes. Izzy has managed to stay fairly quiet through all of this exposition, probing the other three with questions. At the end of the scene, we see her ambitions as that of a fame-seeker when she reveals her desire to pose naked on a mass market paperback and make her way into New York Magazine as she reveals her breasts to Kate and Martin.

Scene Two leads us into 'Week One' of this journey where the students meet Leonard. Once again, the scene starts mid-conversation, or rather, mid-lecture, as Leonard is unfolding a wild tale of one of his many international travels, trying to 
illuminate to the students that they are living in a privileged world. His style is quite tactless, though; and he comes off extremely condescending, wild, and adventurous. Kate has presented her story, a "sardonic commentary" of Jane Austen's Pride and Prejudice and Leonard demolishes it in front of everyone. After insulting Kate, leaving her speechless, Leonard asks for the next story. No one comes forward and he makes his grand exit calling them all cowards. Douglas and Izzy skip out quickly, leaving the tension behind them to partake of wine. Kate, enraged by Leonard's misogynistic assessment of her writing; and Martin, flabbergasted by Douglas' sleazy attention to Izzy, quickly fall into a debate over what is acceptable writing and what the expectations of good writers are. Martin lets it slip that he thinks Kate wrote a really terrible piece before he realizes what he has done. Kate goes to kick him out of her apartment only to have Martin ask to live with her. He has been kicked out of his place because he cannot afford the rent. The scene ends before we discover Kate's decision.

Lights come up on 'Week Two'. This time, Izzy has brought forth a piece of writing for Leonard to look at. Leonard manages to get several digs in at Kate's story from last week, eluding once again to sexist views, leading Kate to lash out. As their argument peaks, Leonard snaps at Kate, trying to silence her by telling her it was not her story he was talking about. He reveals it was a "relentlessly talent-free story about some girl who had this obsession with Jane Austen," not even realizing that it was indeed Kate's story he was remembering until Martin and Kate both confirm she had written that. To add salt to the wound, Leonard picks up and moves on to Izzy's story, a mere two pages filled with sex, and praises her work, defending it from any possible criticism. This class ends with an ambiguous offer or suggestion that Leonard and Izzy's relationship might be more than that of a professor and his student.

Immediately after this event, the play picks up the story with Kate and Martin in the apartment (she has, indeed, agreed to let Martin live here), pigging out with a bowl of cookie dough over their sorrows, arguing whether Izzy's story was actually any good or if it was a matter of the men wanting to 'get lucky' with her. A moment of sexual tension peaks as Martin teases Kate, she climbs on top of him to wrestle the food from him, and as they realize their proximity, both waiting for the other to lead into it, the doorbell rings. Douglas storms in ranting about Leonard and Izzy hooking up. Martin 
refuses to accept that this could happen because it would be "unethical." As Kate laughs at the boys for being so naive, Douglas steps on her toes, defending Izzy and blaming Leonard. Kate, outraged that neither one of these guys can see the truth behind Izzy, engages in a full screaming match with Douglas. Once again, the doorbell interrupts as the 'wallowing-in-self-pity' Chinese food has arrived.

The following topic of the seminar is Douglas' piece. 'Week Three' unveils that The New Yorker is looking at publishing this piece, so we know there is some validation behind Douglas' work. Martin, unable to hold his tongue, lets it slip that he is much less than impressed with it. Leonard, a catalyst to conflict, pokes and prods Martin to let his real feelings out using the word "pussy" a good seven or eight times for effect. Martin refuses. Leonard then lights into Douglas calling his writing whorish and tells him he will never make it as a novelist, that he should go to Hollywood to write fluff. Once Leonard has left them all in his wake of destruction yet again, Douglas storms out and Kate follows to try and comfort him. Finally, in a moment by themselves, Martin confronts Izzy in his pouting, accusatory way, of 'screwing around' with Leonard. The sexual tension between the two can no longer hold and Izzy comes onto him, leading him to his bedroom. Kate comes in the front door as they exit, crestfallen from overhearing the two of them.

The next scene opens on the fourth class of the seminar. Douglas and Kate are having drinks and she is showing him a piece written by a Cubano transvestite gang leader she plans to show to Leonard. She tells Douglas that she wants to quit the seminar, to quit writing entirely. Martin and Izzy interrupt this chat with a sexy chase throughout living room in their skivvies, only noticing the other two in the room when Kate calls them out. Kate has a little meltdown in front of Douglas, making known her displeasure with the lovebirds living with her and the inability to be appreciated as a writer, moments before Leonard shows up. Leonard barges through the door after two weeks in Somalia, to immediately hone in on all the uplifting and enlightening details of third world war-torn countries. He advises Douglas that is where he should go if he wants to be taken seriously as a writer. Kate, no longer really caring what Leonard thinks about her, snaps at him for giving crappy advice. She gets Leonard to pick up the new piece, but he immediately dismisses it when he finds out it is not written by anyone 
in the seminar. Kate tells him she's quitting, Leonard admonishes her for her weak will, and their fight quickly escalates back to the focus of her story in 'Week One' where Leonard tells her that the critics will only be more harsh in the real world. A shared moment of sad realization is interrupted by Martin and Izzy as they barge into the room. Leonard starts to read this Cubano piece and likes it. He tells Kate to bring this new writer in.

The story jumps forward a mere few hours to later that same evening. Leonard has left and the four writers have been drinking. Martin is reading the Cubano story, prodding Kate for information about the writer, when she tells Izzy and Martin that she plans to sell her remaining portions of the class to the mystery writer and move to Ohio. Martin, unable to take the thought that this guy might be a better writer than him, hounds Kate for all the fine details. He figures it out. He accuses Kate of writing the piece under a pseudonym. Kate's moment of glory has come! She unloads on all of them-she did write it; she is annoyed with Martin for bumming free rent off of her; she is tired of sex-craved Izzy and Martin parading all over her apartment; she is fed-up with Leonard for making her feel like shit; and she is, indeed, a good writer. Since the alcohol has loosened tongues, Douglas, too, feels the need to blow off some steam. He broadcasts to all of them that Leonard is a plagiarist. The party breaks up pretty quickly after that. Opinions of Leonard's guilt are stated and rejected. Kate rails into Martin, shutting him up once again, making fun of him for not showing any of his work. One by one, the others abandon Martin. Izzy leaves him with the challenge, "You have things to do."

In 'Week Five' Leonard starts with the topic of the Cubano transvestite gang member again. Kate tells Leonard she has decided not to leave after all and there is a moment where it is ambiguously understood by everyone that Leonard knows Kate wrote the piece. A respect for one another is finally established. Gears shift abruptly as Martin steps up to the plate with a piece of his own writing. Leonard cannot believe how fantastic the writing is and praises Martin for it. Through the course of finding out where Martin came from and how he got into the seminar, it slips that Leonard and Izzy have been screwing for weeks. Martin, unable to accept his talents and believe that words of promise mean so little to writers, lashes out at Leonard. In his rant, he states his 
frustrations with Leonard's unorthodox ways of critiquing, ultimately driving it home by calling Leonard a plagiarist. For the first time, Leonard does not instantly speak. He slowly lets Martin's words land on him and affect him. Then Leonard reveals all. $\mathrm{He}$ drags us through a vague outline of what Martin's life will be alluding to his own history. He rails on and on about the difficulties Martin will face as a writer who wants to pave the path alone, refuses to accept help when someone tells him he is talented, and ultimately is scared of what he could be. Leonard storms out, leaving all four young writers reeling in his wake.

The final scene takes place several weeks after the last class. Martin shows up at Leonard's to collect his money for the remainder of the seminar classes for which they did not meet. Leonard makes it very apparent this is bad timing because he has got a guest. While this is not shocking news to anyone, the fact that Kate is the guest, is. Kate walks out in underwear and one of Leonard's shirts, unbuttoned, leaving no doubt that wild, explicit sex occurred between her and Leonard in this place. She exits to get dressed while Leonard accuses Martin of walking out on the seminar. A fight is about to break out when Kate comes back on to convince Leonard to give her and Martin some time alone. Once Leonard has left to shower, Martin confronts Kate and accuses her of sleeping with Leonard to get back at him. Kate snaps. No longer able to take Martin's self-centered egotism, she berates him for taking advantage of her when all she was doing was trying to help him. Martin tries one last tactic to grasp onto reality and kisses Kate. With Kate's rejection, Martin is lost. He has no retaliation while Kate explains that Leonard is actually a good mentor: he hooked Izzy up with Salman Rushdie, set Douglas up with the Weinsteins, and got her a job as a ghost writer. Martin scoffs at her new job, and Kate scolds him; not for looking down on her, but for looking down on himself. She tells him to "just live it". She leaves the apartment on a powerful note, for she finally knows herself and her place in this world.

Left alone in Leonard's study, Martin comes across some of Leonard's fiction writing. Leonard enters as Martin is deep into reading it. Leonard wigs out, cuts Martin a check for the untaught seminar classes and tells him to get out. Martin wants to know why Leonard does not write anymore. Leonard reveals his vulnerability, his inability to tolerate his work as good or even acceptable once he has finished writing it. The two 
men bond as they come to a common understanding of the sanctity of words. Leonard offers to help Martin, to really help him, if Martin promises to step up and take the criticism. The story ends with the two sealing the deal by sharing a drink, in the absence of words. 


\section{CONCEPT}

From the moment of the initial read-through, the endeavor to piece together this play was very clearly going to be a communal effort of each individual in the cast. The director, Professor Lee Blair, did not step out and say, "This is what the play is about and this is how we are going to do it;" rather, he asked us, the cast. One by one, we would offer up ideas, fragments, of what the play was "about." The conversation grew rapidly, we overlapped one another, we eagerly added input to make the thoughts more complete. Although this discussion was started the first night at the table read, it was one opened back up at least a couple times every week throughout the entire rehearsal process; because new ways to word it were continually discovered, or the definitions would change and mean something new to either the actors or the director and the discovery needed to be shared. Through this approach by the director, the play grew organically. Creation flourished in the freedom to explore rather than determine the right path the first time.

The script itself, Seminar, is about truth and honesty. It is the discovery of personal truth, what our personal place is in this world. Through the entirety of the play, each character is struggling with defining their 'role'. They all want to be the next great writer and to be perceived by their peers in a certain light. By the end of the play, each of them comes to some realization of who they are. Once the characters realize their personal possibilities within life, they are open about it with the others. There is no more hiding desires and action, for there is no need to. These meticulous crafters of words have finally defined themselves.

The scenery reflected this concept of "truth and honesty" by monochromatic color schemes and sparsity. As dictated in the script, there is not a need for much by the way of furniture. In Kate's apartment (Scenes 1-8), there are two chairs, a couch, and a large coffee table. Scenic Designer Joe Dotts added a few more pieces to make it more livedin such as a bookcase, pictures, artwork, and other small set dressings. Everything was done within the scales of whites, grays, and ice blues to echo that sound of bleak uncertainty of personal definition in each of the characters. The floor was treated to look like a polished concrete, the colors blending into the insipidness of the walls treated to implement a rough and spiked texture. The most striking and poetic image established 
on the set was the fading of the walls up into a cascade of papers. The top of the walls were covered with manuscript papers and thinned out as they climbed higher to the grid of the theatre. This effect gave the impression of drowning in one's work, writing for days, not knowing if the work is good or awful, simply spitting it out to land on something. Throughout the course of the show, Professor Blair and Dotts added additional paper scattered on the floor: in each scene shift, more and more papers would be thrown on the floor to demonstrate the passage of time and copious amount of writing happening. Later in the play, as the final scene takes place in Leonard's apartment, the furniture and dressings would change to give a greater range of color, showing a warmth in the well-versed, self-established Leonard.

Costumes were designed by Professor Mary McClung to articulate personalities of the characters. Colors were used more freely here than in the set, signaling to viewers a defined sense of self projection within each of the characters. For instance, Kate was to be costumed in sweaters and cardigans, giving her something to 'hide' under. She was costumed conservatively: in solids, beiges, khakis, browns, blues, capris and button-up blouses. Kate very much so had the polished look of a middleaged woman, suggesting she felt most comfortable with maternal relationships and did not have a strong social connection to young adults her own age. Once again, the costumes embodied the sense of concept of "discovery" as they evolved through the course of the play.

This concept is a universal conflict and desire so making Kate relatable was not difficult; it was trusting myself to be honest with her that was. A challenge that each actor in this play faced was this vulnerability. That is why the concept of direction that Professor Blair brought to the rehearsal hall was necessary, why this approach of group discovery was as delicate and important as the message of the play. There was a freedom to create, to pour myself entirely and truthfully into the story. 


\section{RESEARCH}

As mentioned in my Introduction, I was hesitant to begin with Kate. I had read Seminar at the recommendation of a fellow graduate student while searching for scene study material the previous semester and fell in love with it. Once it was decided to be included in West Virginia University's season, I was excited. I knew Kate was for me. This was my role. Obviously, I was confident going into auditions. The actor's mind is flexible with imagining different scenarios, so quite predictably I went through fluxes of extreme excitement and positivity, and then frenzied stress of not landing the role. I was already on the road home for summer vacation before the cast list went up and before I received the email. I was ecstatic to begin working. The weeks leading up to finally getting the script in my hands were excruciating. Once I had it in my possession, though, I could not bring myself to pick it up.

\section{Understanding Literature}

Before the script came in, I stumbled across How Novels Work by John Mullan in a used bookstore. This particular book goes into detail concerning the many perspectives and techniques that can be woven together to create a novel. The areas covered were general in a sense: the beginning, narrating, people, genre, voices, structure, styles, devices, etc. It was underneath each category that hundreds of subcategories fit in (i.e., the Voices chapter entailed: dialogue, languages, translation, phone conversation, clichés, swearing). This book quickly illuminated the structure of novels that as a reader for enjoyment I had never thought of, but it also showed the limitless possibilities in creation. Early in reading the novel, I developed this grand scheme to read all about the different styles of writing and how characters are contrived along with plot and narrative, ultimately planning to write my own story. In Seminar, Kate writes two of her own stories. It felt necessary to originate these stories myself in order to be honest with my creation of Kate.

The magnitude of this undertaking was quickly illuminated as progression continued through How Novels Work. Approximately two-thirds of the way through the book, while taking astute notes, I came to the realization that it would be impossible for me to become an intelligent writer in this amount of time, and more importantly, that it 
was not necessary. A grasp on the art of writing novels and the appreciation for such art was established from the reading. Personally living in a world where the creation of literature is not prominent, it was necessary to develop this understanding and appreciation. Establishing this comprehension of the nuts and bolts would lead me to begin attaching an individual meaning and passion to the writing of Kate; however, there were still plenty of references to the literary world in the script that went beyond the average reader's knowledge. This meant reading fiction, a research that I welcomed.

I started with Salman Rushdie. In the script, Kate eludes to the fact that he is lust driven: "He introduced Izzy to Salman Rushdie who is a huge flirt and wants to help her with her drug whore book."2 Obviously his work is respected because it is known, but clearly there is a distaste for his voice and subject in her perspective. After reading his Fury and The Moor's Last Sigh, I found him fascinating. Rushdie is heavily influenced from his Indian heritage, sex, the physical absence and presence of one parent versus another, and carnal lust that drives the characters almost against their will, constricting them from obtaining power in relationships. All of the perceptions and conflicts that can arise from such obstacles are written in a strong image and poetic-based flow. Needless to say, it is enticing. After reading him for a while, though, the voice of his novels became a bit predictable. While two novels are not enough to develop a full appreciation for an author, the exposure was enough material to come to a conclusion about his writing style and voice. Further research illuminated the controversy over his fourth novel, The Satanic Verses. He was accused of blasphemy against Islam in such an extremely violent way that he was forced to go into hiding under protection of the British government. ${ }^{3}$ Kate's comments of him in Scene 9 as a man "who is a huge flirt" and wanting to help with a "drug whore book" 4 leave us with no doubt that Rushdie is an author that provides contentious reaction.

Jack Kerouac was mentioned with such solidified opinion by the characters in the text that I waited a bit to read him. As Kate references him more frequently through the script, and with clearly defined opinions of him and his work, it became necessary to

\footnotetext{
2 Rebeck, p. 66

3"Salman Rushdie."

${ }^{4}$ Rebeck, p. 66
} 
read a larger quantity of his books compared to the research of Rushdie. Upon my first introduction to his work, I fell in love with his writing. It was simple and poetic and had a driving rhythm that moved through your body, like he was reaching right into your soul. After I read a couple more books, I began to see how he has a recurring theme in this script. Kerouac's writing draws the reader in on a personal level and the narrator is always in pursuit; though in pursuit of 'what' is not clear. The characters in Kerouac's novels are on a journey, just like all five characters of Rebeck's Seminar. After finishing up with the iconic On The Road, I felt I had established a solid understanding and sensitivity to his voice of narration.

In addition to reading Kerouac, I had the chance to visit his old stomping grounds in San Francisco. I toured the little museum of beat poets where they had props and pieces from the film version of On The Road. I stepped in the City Lights Bookstore 5 to soak up the ambience. I walked down Kerouac Alley. Walking around the part of town he frequented illuminated the dirty nomad that was so strong in his writing. It took away some of the magic, seeing the reality (the burlesque houses, run-down bars and takeout joints, the insignificance of this intersection within the hub of the rest of the city). I found this to be a strangely poetic discovery in line with the concept of the play and growth of Kate: real life demolishes the poet, the carefully crafted text describing life. As authors, control of creation can be had. As human beings, control of reality cannot.

August quickly approached, leaving time for the novelty of immersive research at a bare minimum. Having read a couple Jane Austen novels, it was necessary to read Pride and Prejudice to steep my roots of Kate in the work and ideals portrayed. This novel was one I chose to read as rehearsal began. During the rehearsal process, the actor is busy creating a character and discovering their internal and emotional make-up. Jane Austen, as a role model for Kate, was the basis for her romanticism, morality, structure, and feminism. The social commentary in Austen's work was revolutionary in her era, causing a peak of popularity in her works. This is the very thing that makes Kate tick. This needs to be relevant in her writing. To be biting with her ideas while

\footnotetext{
5 The City Lights bookstore is home to Bay Area thematic writers who were looking for change: a political and revolutionary call within their writing. This bookstore is known for publishing and holding to these concepts of many of Kerouac's contemporaries, most notably Allen Ginsberg's Howl. "A Short History of City Lights."
} 
camouflaged by the "prettiness" of her characters and their world is what Kate desires to be. This has been what she has known and grown with; therefore, it must be what she desires.

\section{Text Analysis}

The first sentence of Pride and Prejudice is as follows: "It is a truth universally acknowledged, that a single man in possession of a good fortune, must be in want of a wife." ${ }^{6}$ In the script, at the top of scene two, Leonard is discussing Kate's first story: "'When truth is acknowledged universally it is also universally disdained.' I mean what

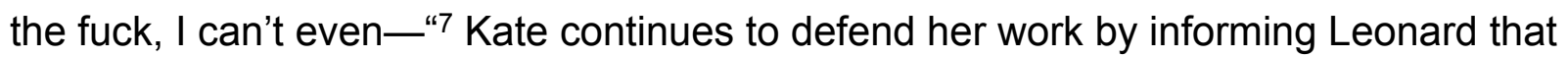
she is making reference to Jane Austen's Pride and Prejudice- "it's kind of a sardonic commentary."

It was a little bit into our rehearsal process before I began reading Pride and Prejudice. Every time in rehearsal I spoke the line about "sardonic commentary," I could not fully understand or appreciate what I was saying. Once I cracked open Austen's novel, a key element of Kate was revealed. I could not help being thoroughly tickled by Kate's cutting contempt for societal prejudices. Kate's first story is based on the writing of Jane Austen and is a point of contention between Kate and Leonard, Kate and her fellow students, and Kate and herself through the entire show. She is judged for her story, judges the others for not "getting" her story, and bases all of her work off of this single story. Kate identifies herself within the work left behind by Jane Austen.

The script alludes to the fact that Kate was exposed to a similar environment as Jane Austen, who was raised in an environment of creativity, free learning, and conversation. This framework of nurturing learning and curiosity leads Kate to live for praise. She becomes petrified of negative critique and strives to be applauded for her work to the point of ceasing any creation of original work. As the play progresses and she is shocked by Leonard's denial of her masterpiece to be labeled as such, Kate, much like her idol Jane Austen, comes to the realization that it is a man's world. She leads the resistance and plays the game, outwitting the leader in his own masochistic

\footnotetext{
${ }^{6}$ Strange, Austen, Strange, p. 1

${ }^{7}$ Rebeck, p. 16
} 
monarchy. Jane Austen herself had to fight the societal prescribed notions of the male as the dominate power: men determined her writing worth, men controlled the publication of her work (specifically referring to Benjamin Crosby's iron grip on the publication of Susan), and the gender of men dictated her living arrangements. ${ }^{8}$ Just as Austen prevailed in this world, the growth of Kate demonstrates a relevant parallel.

It is important to note the script is not brimming with historical accuracy or events of the past. It is a contemporary play with a few characters based in stereotypes, but far from stereotypical. Most importantly, it takes place "in the now". Discoveries and revelations happen throughout the show and most of what is discussed in this thesis is personal attachment and application. The portrayal of Kate is based in the necessity of finding personal truths and their application to release the actor of representing a stereotypical Kate.

A blatant truth found in the text, not just for Kate but for all of the characters, is their isolation. There are moments within the text alluding to personal backgrounds and people of influence to each individual. These supporting facts or parts of the characters' backgrounds are not heavily referenced because they are not important. Rebeck gives the flavor of Kate's family life by lightly touching on the facts that the apartment is her parents' city get-a-way. It is obvious she comes from money since the apartment is rentcontrolled and she went to Bennington. She is probably an only child (no other siblings are referenced), and this all adds up to her living a sheltered and comfortable life. While all of these factors are important in the roots and foundational development of a character, their absence during the action of the script demonstrates their immediate irrelevance. This illuminates the important issue: the characters are discovering their truth, their place in the world and society; a self-truth unencumbered by subjective judgment and driven by self-desire and definition.

Speaking the text itself proved to be more mentally exerting than originally perceived. Like other contemporary scripts, the text is steeped in subtext. Unlike most other contemporary scripts, the timing of the text is as precise as poetic plays, comedic shows, and David Ives' work (case in point: All In The Timing). It is as clearly articulated through punctuation and syllabic rhythm as Shakespeare. Meisner's technique of

8 Warren. 
reacting from what the other actor presents you, honestly and truthfully in the moment, applies to the motion of this piece. His method of 'working readings' (eliminating punctuation and capitalization to void the text of any instantaneous meaning) does not. Punctuation is a strong clue to the actor of when to pause, when to overlap and when to allow a change in thought. Often, the text is repetitive, fragmented, or with lengthy runon sentences, making it impossible to memorize the line without first establishing and memorizing the clear thought-process of Kate. For instance, in Scene Seven when all four of the students are hanging around after their recent seminar session with Leonard in which Kate produced the Cubano transvestite gang member's story, she speaks these lines:

KATE. I told you, Martin! He's this guy I knew from Bennington and I know you think that Bennington is some sort of crazy Vermont hippie commune where people get stoned all the time and no one can actually write-

MARTIN. I never said that-

KATE. You so did and I don't care, I'm just telling you, this guy was at Bennington when I was there and he's a good writer and I don't want to do it anymore so he's going to take my spot. I need the money. I'm going to Ohio. ${ }^{9}$

And a short bit later in the scene:

MARTIN. So you've read it, this guy's story?

KATE. It's not a story it's a memoir.

MARTIN. And it's good?

KATE. I liked it. I think he's a really good writer, and he's kind of cracked, he wears dresses you have to put up with that, but he's nice and he has an interesting history and he can write. ${ }^{10}$

Examining the text from Kate's point of view, we can see the clear shifts of thought within this text. The moments when the text is short and concise, she is speaking an absolute truth. It is a fact in Kate's mind that it is not a story, but it is a memoir. However, within the lengthy sentences where it seems like Kate is just testing her lung capacity are the moments when she is lying. She is fabricating the story of this

\footnotetext{
${ }^{9}$ Rebeck, p.48

10 Rebeck, p. 49
} 
'Luis' guy and her nervous habit is to overdo the description. Her thoughts continue to move quickly and search for an answer that is descriptive enough that it will suffice to propitiate her peers. The clipped sentences at the end of the first example are little addons, a pinch more of seasoning to her story to try and sell it. A similar tactic is used in the second example, listing the attributes of this other writer, trying to stitch together a more complex person in as smooth of a stream conscious as she can muster.

In addition to the thought process needing to be thoroughly mapped out in order to produce the correct timing, Seminar is a comedy. With any such script, timing is everything. This aspect, while typically easier to comprehend and apply once a mining and mastery of the text is completed, proved to be a greater challenge for the entire cast. All of these characters' points of view are acutely self-saturated; it became difficult to see the importance in another's lines objectively. This is the essential role of the director in the process of Seminar. Professor Blair guided the cast to view their individual text as the most important thing to say. Whatever we had to say in the script would, in our own perspectives, trump anything else at that moment. This illuminated the building of circumstances to that pivotal comedic moment and naturally caused a build in flow or rhythm and tempo. Professor Blair also gave the note to each one of us to decipher when in the text we know our character is being witty, when we do not know, or when we are not trying. This, too, illuminated the build of the script to the heightened moments of comedic relief. Tensions mount as we either firmly and subjectively believe in our point of view in the exact moment or whether we are prodding another to their breaking point.

\section{Image Research}

Being personally unfamiliar with the details of the artistic literary world, there were many locations, in addition to the authors and vocabulary I mentioned previously, that required attention. It was apparent that Bennington, shown in Fig. 1, was a school that Kate attended; however, there were several references to Yaddo and MacDowell that were ambiguous to me. Further inquiry lead to the discovery that both of these places were artists' communities. Bennington is a private school with a prestigious 
writing program in Vermont. ${ }^{11}$ McDowell (see Fig. 2 and 3) is the oldest artists' colony in the United States, hosting thousands of artists including Leonard Bernstein, Thorton Wilder, Aaron Copland, Milton Avery, James Baldwin, Spalding Gray, Suzan-Lori Parks, and Meredith Monk-just to name a few. ${ }^{12}$ Yaddo (Fig. 4), located in Saratoga Springs, New York, is another illustrious artist colony housing artists who have collectively won 71 Pulitzer Prizes,

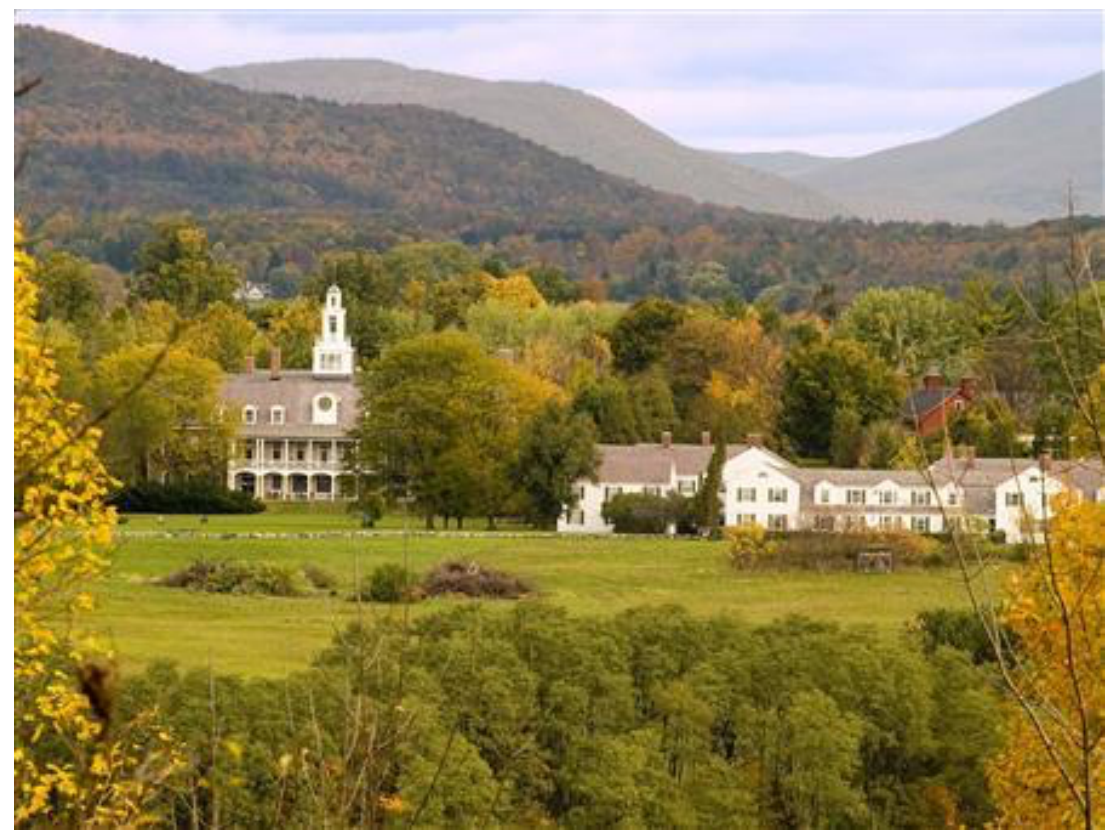

Fig. 1. A view of Bennington College.

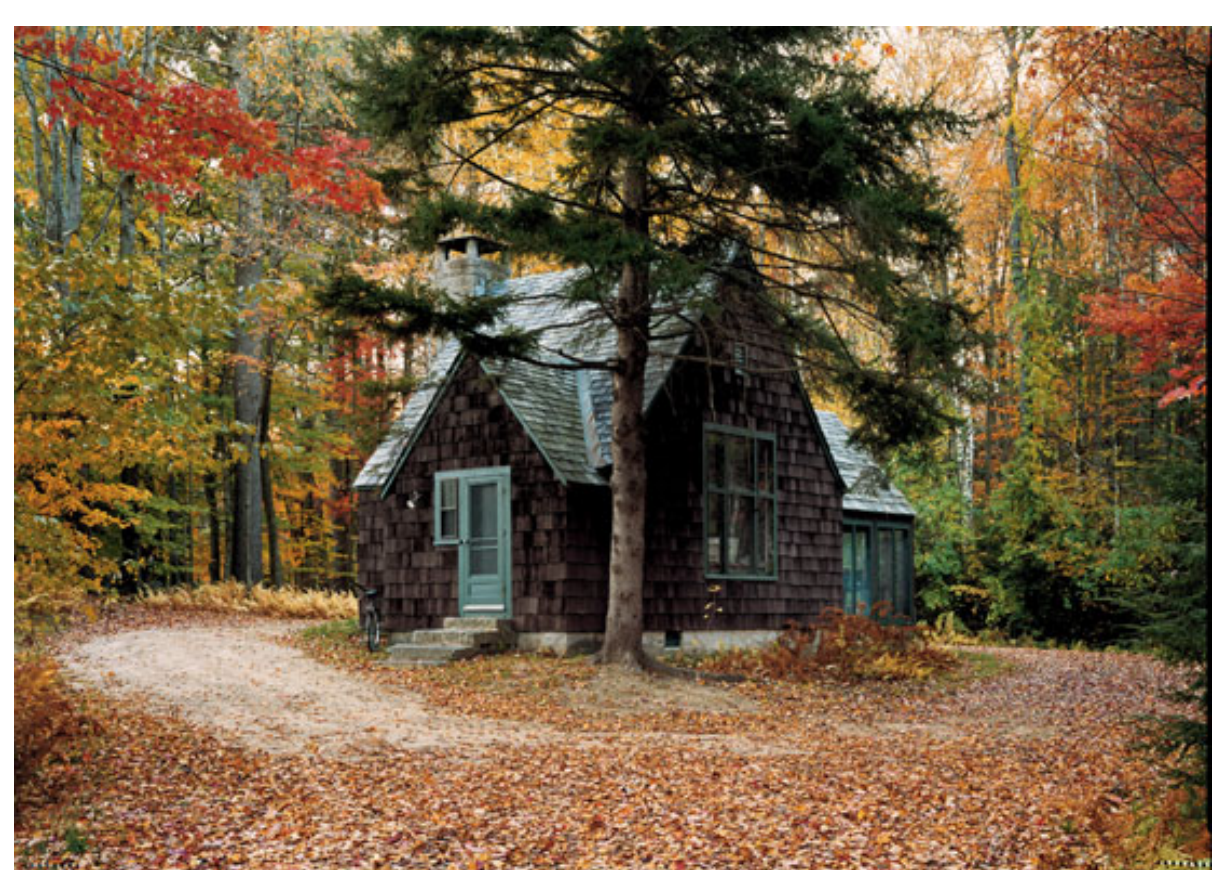

Fig. 2. One of the several artist studios at the MacDowell Colony.
29 MacArthur Felowships, 68 National Book Awards, 42 National Book Critics Circle Awards, and a Nobel Prize among many other awards. ${ }^{13}$ All three locations being within 120 miles of each other, Kate would have been

\footnotetext{
11 "Academics/Areas of Study/Literature." School website for Bennington's writing program. 12 "The Macdowell Colony."

13 "History."A brief history of Yaddo's historic guests.
} 
familiar with each, as well as the literary names flowing in and out of each location. It is imperative to understand that not only were these prestigious places where creative minds gathered to submerse themselves in their work; but in order to maintain a standard of quality, artists must apply for residency. This factor is implied in

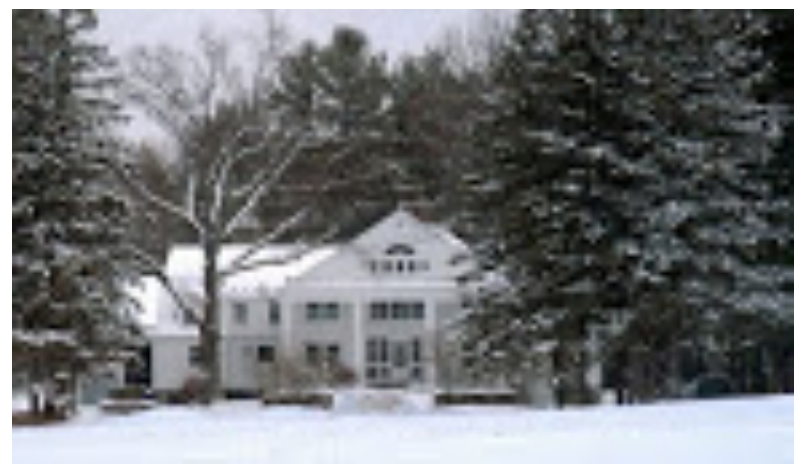

Fig. 3. Colony Hall at the MacDowell Colony, Peterborough, N.H. the script, but in order to fully understand the awe the others have of Douglas' attendance at these places, it is necessary to understand the process of applying and the routine of living in these colonies for a month or so at a time.

While it is not enough to know an author by merely knowing their novel titles, it is also not enough to know a place by discovering an image to associate with it. The images shown here are just a few of the examples collected to expand my understanding and imagination. With a large portion of my research on facts complete, the process of rehearsals would only unfold more 'research' of the growth of Kate and myself within her.

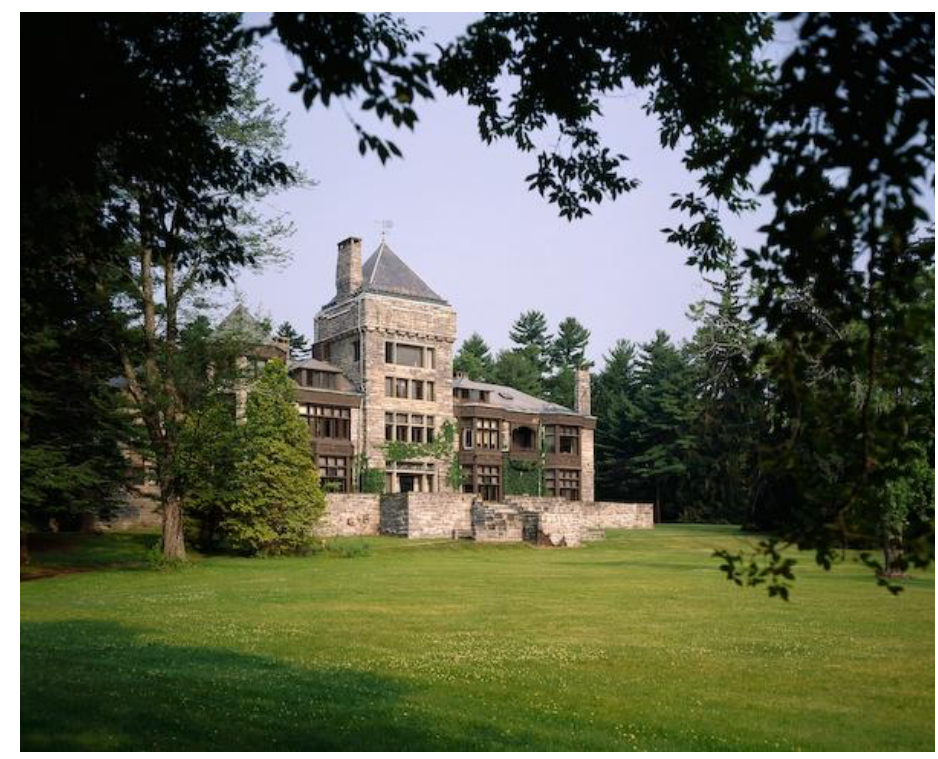

Fig. 4. IUD Writer's Colony in Saratoga Springs, NY. 


\section{PROCESS: From Page to Stage}

The remainder of the work done in the portrayal of this thesis role was completed in the rehearsal hall and within the confines of my imagination. Through interaction with fellow cast members, guidance from the director, use of Meisner technique, frequent referral to the text, and cultivation of my own creative powers, Kate came to life. All of the work described previously was done in the days, weeks, and months before rehearsals began. Once the initial read-through happened, it was too late to be hesitant any longer. Concurrently, it was no longer an issue. Questions had been answered, concepts were explained, and the other characters were now given life as well: the framework had been laid. It was now up to me to create the inner workings of Kate. ${ }^{14}$

\section{Creating Kate: Image Based Research}

The imagination is a radically different tool to each individual. The years spent in school are cultivating ones as we each ascertain which style of learning we best function in: auditory, visual, or kinesthetic. While everyone uses a combination of the three styles, the majority of my personal comprehension and creating falls into the category of visual. I think in pictures. I have to visualize descriptions and directions before I can comprehend them. It is through this need of imagery that I found a strong connection to the process of image research passed on to me by Professor Roger Smart. In his acting class two years ago, students were assigned to find a small collection of images that spoke to the character and scene they were working on. Often creation of character relies so heavily on text analysis, raw emotion, or another estranged notion of what the final product should be, that we forget to create. This idiosyncratic approach to the psyche of the character allowed for a unique interpretation of who they were, never before imagined in quite the same way.

The process of hunting for pictures (which I have found to be most fruitful), is one that takes time; however, not so much time that I overthink. Obviously, a thorough reading of the script and understanding the basic arc of the character is necessary.

\footnotetext{
14 The perspective of character versus actor switches in the following writing. The use of 'l' refers to myself as the actor unless directly quoting from my journal. In the journal samples, first person narrative is from Kate's perspective.
} 
Once it is defined in generic terms what the character wants and feels, it is time to let the imagination take its turn. Next, I spend hours and even days searching for images. Resources are unlimited: galleries, art books, Pinterest, museum websites, blogs, and even search engines such as Google. My personal preference is to keep the count somewhere between six to twelve pictures. Fewer than six images do not provide adequate options to penetrate into all corners of the character's mind, while more than twelve makes the work shallow and too thinly dispersed to root deep enough. Pictures looked at through the search do not need to be stared at and reflected on. The image will either resonate with the actor or not. Dwelling on the image comes later.

Typically I gather all of the images within the first week or two of rehearsals. Once I had gathered all of the images that 'spoke' to me, or what I perceived Kate's psyche to be, they were printed, cut, and pasted on their own page in my journal. From here, the work slows down drastically. The images now serve as a constant reference for my imagination. The first journal entry consists of a few sentences (or full blown paragraphs depending on what is flowing in my mind) simply stating why I chose each picture. Every other day during the rehearsal process and every few days during the run of the show, I return to these pictures, reflect on them for a bit, and write whatever comes to mind. The growth of imagination over time is aided with the flow of rehearsals and this discovery process.

It is important to note that point in the process of character development is where I begin to embrace the melding of my personal and factual thoughts and the perspective of Kate's persona. The images are chosen because, as the actor, I have found an aesthetic pleasure in them relating to what I perceive of Kate as an outside spectator. Once I begin journaling, I allow my thoughts to flow from me as the actor and begin to let them flow from the mindset of Kate. Typically, as the journaling continues and I return again and again to these pictures, all of the journaling comes directly from my formulated point of view of Kate. The narration is always in first person, and always from Kate's perspective. The journaling at the beginning is weaker in conviction and does not solidify until I have done more of the free associative journaling to make Kate's voice more concrete and assertive. 
The most abstract image I worked with for Kate is Rainbow by Spencer (shown in Fig. 5 below). It demonstrates the growth of Kate throughout the course of the play:

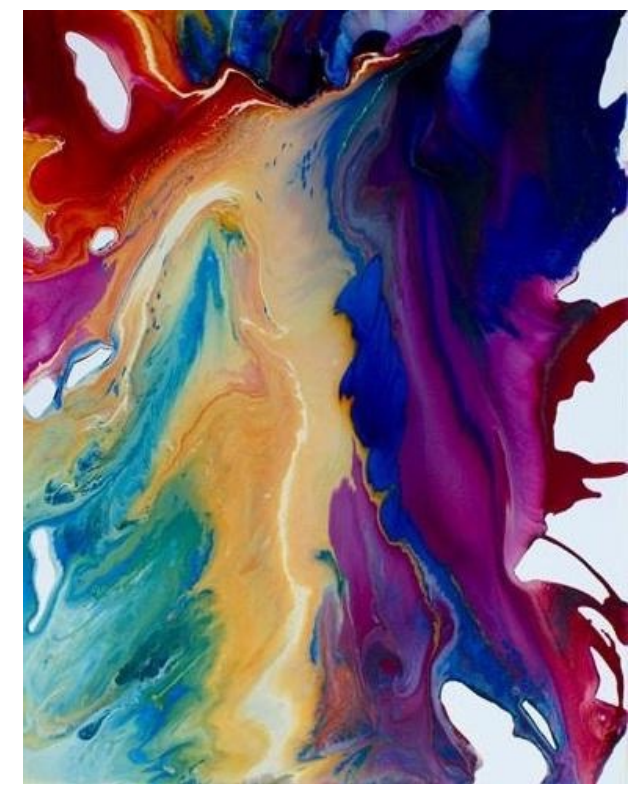

Fig. 5. Rainbow

"start[ing] on the left, colors are more separated. Here I am concerned with compartmentalizing my life, keeping it neat and organized, still trying to stand out. I want to be recognized and deemed worthy according to the work I put forth and my unique style. It's all separate: my writing, my family, my friends, my life. This is all before the seminar starts. The yellow streak is my big growth. This is the time period of my life within the seminar after Leonard has critiqued my story. Everything has crumbled. I'm in shock. I'm depressed-yes-but that's not what is taking over. I'm pissed. He didn't just say my work was 'bad' - he dismissed it. I'm livid. I am itching to react, but it's scattered - I don't know how to direct this passion. Until I decide to play the game. So I do it. I write a story anonymously. And I'm still in the yellow-still in limbo-even once I find out Leonard likes it. Because while I'm validated, it's bullshit. I haven't been recognized for it. The transition happens after Leonard has validated it, but before he knows it's me. This purple and blue mix is me living in reality. And it streams from the far left the whole time-it's always been in me. Now l'm living it. I'm not concerned with separating parts of my life from my writing —it can only help it." 15

15 Taylor, personal journal. 
Finding an image to help with the overall arch of Kate is a necessary step as it allows me to stay on track as I delve into the details of her emotions. Sometimes dwelling on one event in the play can lead to an attachment of a certain emotion without regard for the final objective. This picture kept me grounded to the story Rebeck was telling as I let Kate grow and feel, scene by scene.

The next few images in my search dealt with the central conflict of Kate's growth. Both images selected had the subject of water, speaking to an unpredictable fluidity driving Kate. This first image, titled diamonds (Fig. 6), captures a simple and beautiful moment of nature. Realistically, the consequences of rain falling onto a still body of water span a far larger chain reaction that is not always as peaceful or picturesque. The turbulence observed from below the surface is a more aggressive stimulation to the senses than what is seen above. The initial reaction to this photograph was:

"...bombarded with pellets of raindrops-making the surface's reaction indecipherable as to whether it's exploding or imploding."

At a later date, I wrote:

"....it never hits the same spot twice-so it's difficult to precut and to prevent. It also ripples. So the impact has a lasting effect. One ripple collides with another and into a different one and then yet another. It's chaos. But from a distance, it is beautiful. It is cleansing. It is rhythmic. It washes away the grime and crap. It stirs things up that had long settled at the bottom."16

My reflection became what was happening under

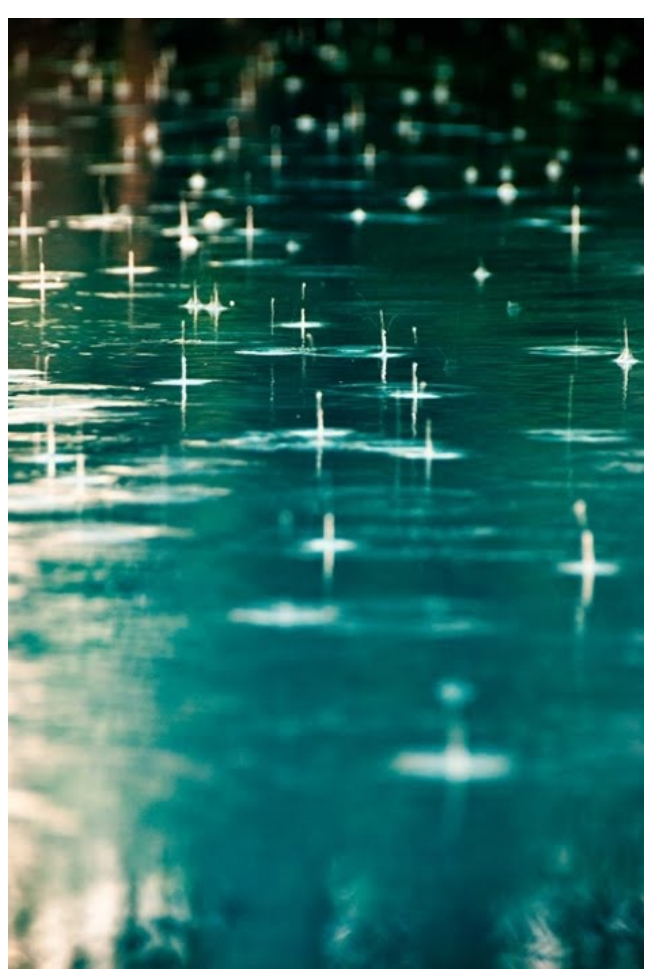

Fig. 6. diamonds the surface of the picture rather than what is visible.

The next image of water (Fig. 7) placed Kate as the subject. It no longer was metaphorical, this subject of nature; now she was a part of it. Once again, the difference 
of above and below the surface of water delineates the point of personal conflict within Kate's mind. Kate is a rather simple, nice, respectable, clean-cut member of society at the top of the show. Once her piece inspired by Jane Austen is ridiculed, the audience witnesses a drastic growth within Kate as she learns to define herself. This sequence of oil paintings by Alyssa Monks outlines a struggle to stay above the surface balanced with the ease of doing so by complete relaxation. The first half of my journal entry for this image is reflection of "bombardment" and the struggle of life as I have known it caving in. Once I allow myself to hit that point of relaxation and floating, the realization that this struggle is not even worth it can permeate the mind.

"...I just allow myself to be overcome by
it. There has to be a sacrifice for the
greater good. The old me must die to
allow room for the new me. So it's time to
let go. Time to say goodbye to innocence,
controlling/compartmentalizing my life,
sheltering myself, my definition of
woman... But I don't know it's
happening."17

There are an additional couple of images I used relating to the pull and desire to change that Kate notices and acts upon. Not only is there a strong desire within Kate to change, but there is also confusion about how to do it. Through the course of the play and the sequence of events that happens week by week, she is changing without even realizing. She has merely allowed it to happen. The images collected allow me, as the actor, to connect to a feeling and identify and correlate it to a specific moment of Kate's journey. The following grouping of images is a selection from the remainder

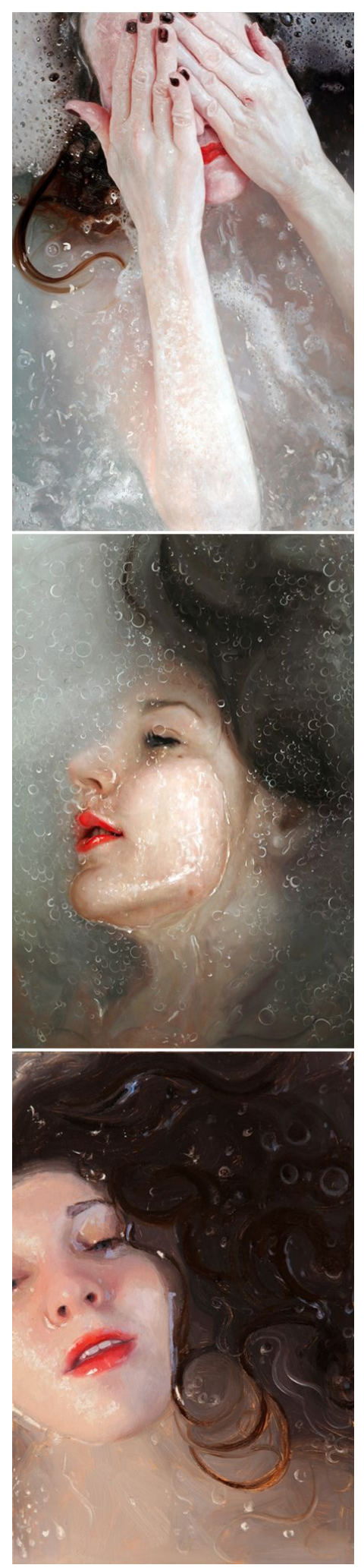

Fig. 7. Collection of Alyssa Monks oil paintings: Tell, Tonic, Allow.

17 Taylor, personal journal. 
of my image research. The images deal with implications of society framing my definitions (from Kate's perspective) of what it means to be a woman and a lady, how she is to behave in public, and it shatters them.

Jones' Smok'in Ivy (shown in Fig. 8) triggered a response to Izzy that I found to be suppressed and driving Kate's actions. There is a desire to free herself and be a woman in tune with her femininity, but she cannot "succumb to the cheap, erotic, sexy storytelling of Izzy. That would only prove him [the misogynistic Leonard] right." 18 This triggers a need in me to retaliate, to find a story, that as Leonard first lectured us, "must be told." 19

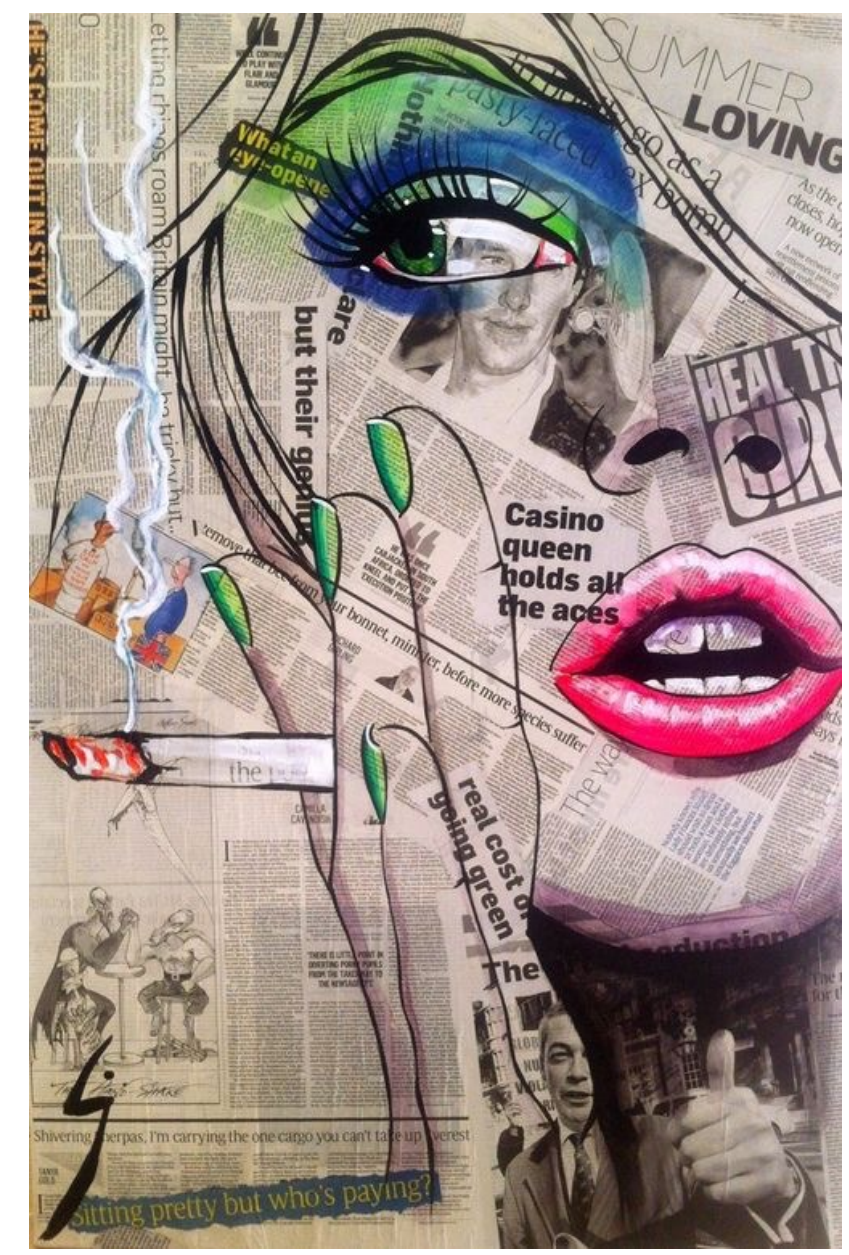

Fig. 8. Smok'in Ivy

\footnotetext{
18 Taylor, personal journal.

19 Rebeck, p.15.
} 
Fig. 9, by Loui Jover, consists of papers pasted in the background much like Dotts' set design. The papers are Kate's life's work. She cannot escape from her writing. It is always present and the base of who she is. The look on the girl's face is one of sensual self assurance, though a hint of discontent in the slight snarl of her lips. It embodies the attempt Kate puts forth with her new story written by her Cubano transvestite gang member character.

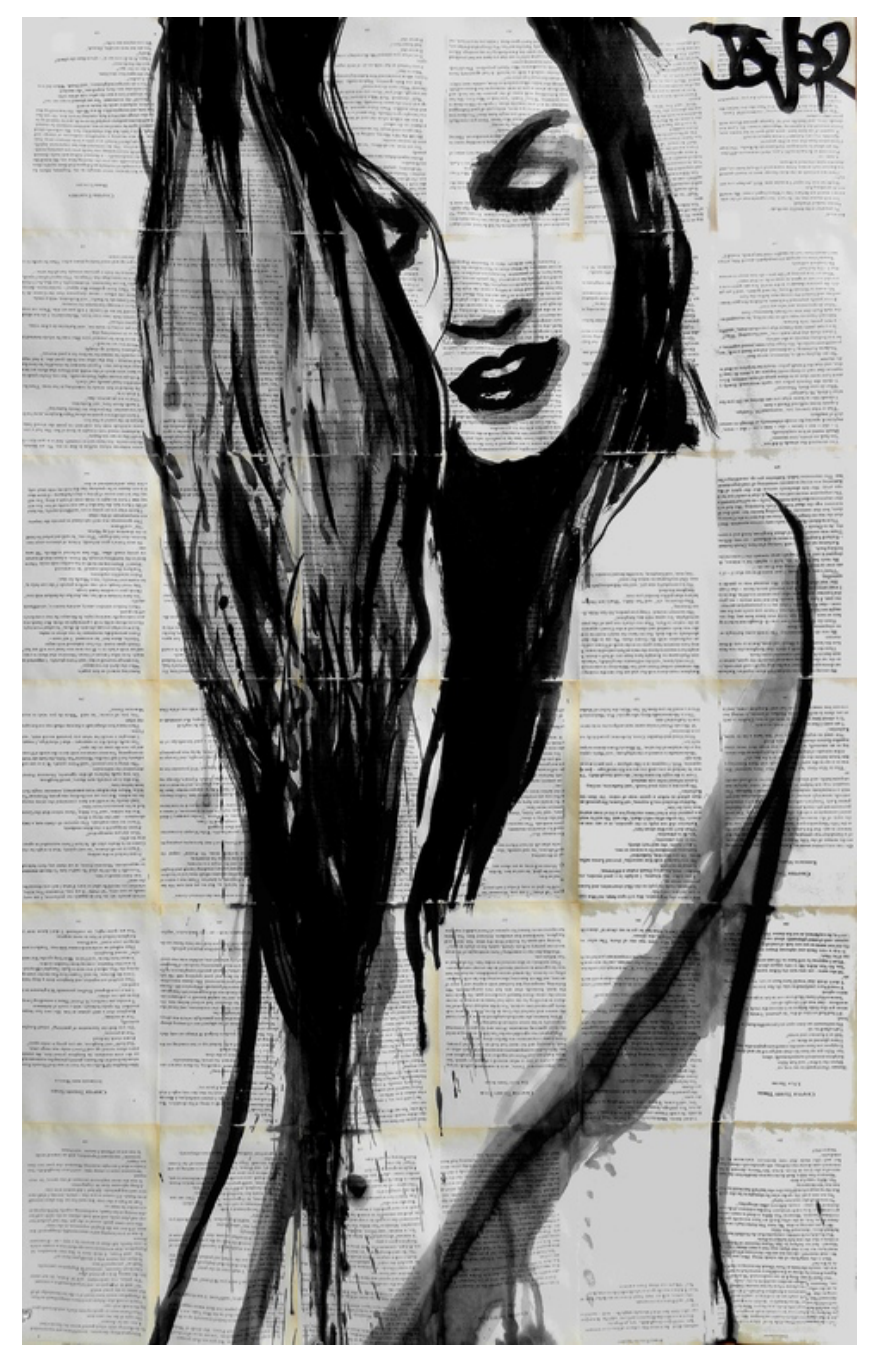

Fig. 9. guinevere

"To write like a man... That's not possible. I can and will write my perspective and judgments of men [as a woman]. It's very freeing. It makes me more of a woman. In such a very unexpected way... I will win. I am winning. I have won."20

20 Taylor, personal journal. 
The last couple of images shown here are clearly very sexual and sensual portrayals of the human body, specifically the female body. Scene Nine of Seminar jolts

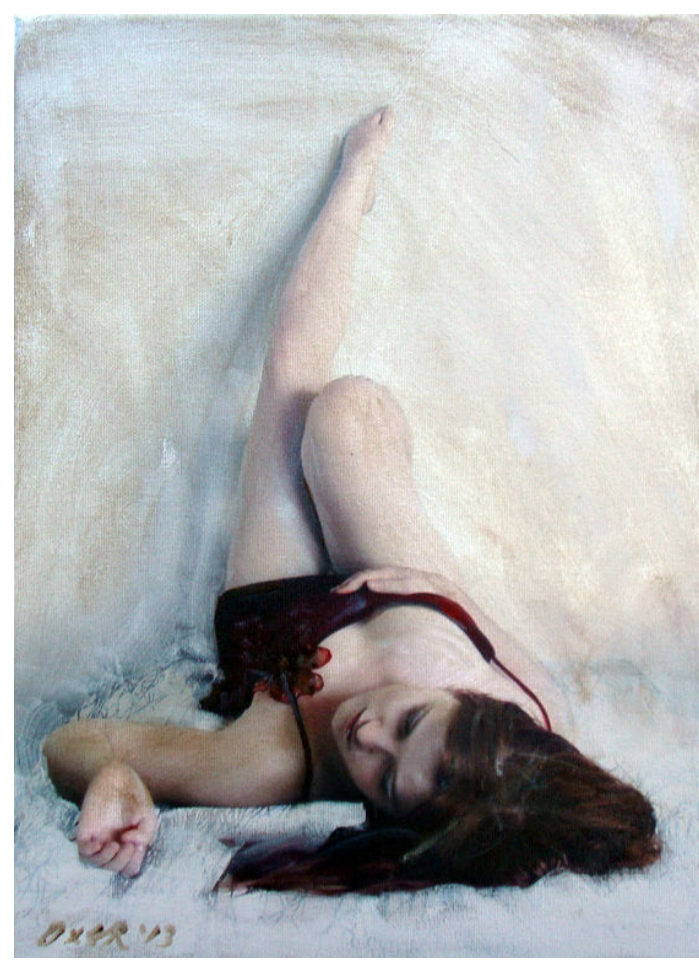

Fig. 10. The Wish Martin as well as the audience with Kate's sexual adventures with Leonard. In order for it to be a surprise, there cannot be a lot of text building to the event. Defining why Kate slept with Leonard was a struggle for me. It is one I will address later within this delineation of my process, as it arose through rehearsal and journaling of the text. However, these images helped lead my imagination into closing some of the gaps left by the author for the actor to fill. While I am not convinced the audience needs to know Kate's reasoning and motives, it is imperative for the actor to make sense of why

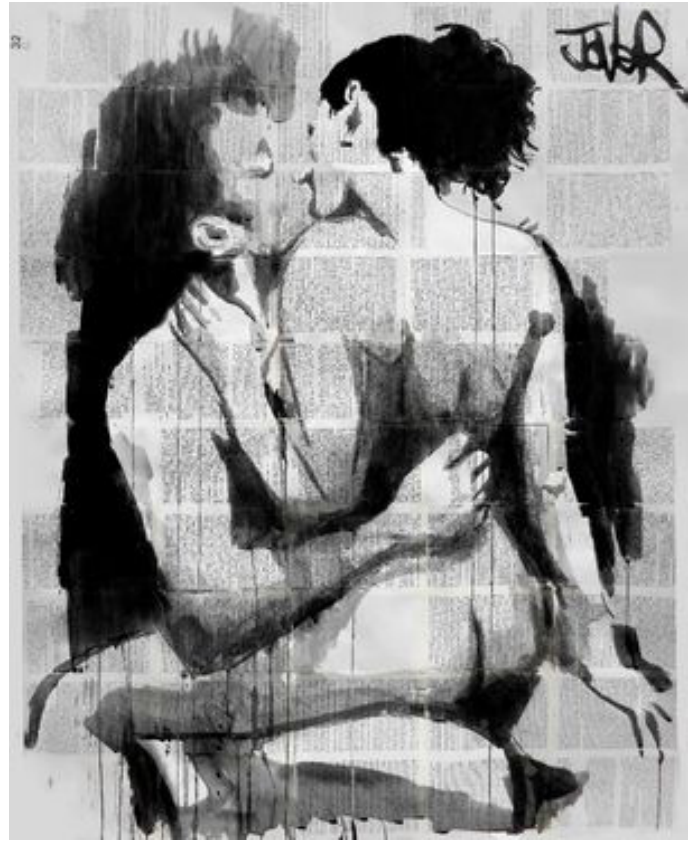

Fiq. 11. tanqo Kate would choose to sleep with Leonard.

Through these images, Kate is allowed to free herself of these constraints and come to the following conclusion:

"Jane Austen only has it half right. Sure, it's about love. But it's about love of self. You have to take care of you before anyone else will. That means doing what feels right for you, regardless of what anyone else thinks or tell you what is right or wrong. You define yourself. You define your happiness." 21

21 Taylor, personal journal. 


\section{Letting the Imagination Flow: Free Associative Journaling}

Once the creative imagination is rolling from the image research, it is easy to be satisfied with quick answers to the basic questions arising through the first few readings. It is important as an actor to let the mind continue to cultivate complex solutions to these questions, figuring out how to get to the answer rather than just accepting it. David Mamet creates the school of thought that actors are to "Invent nothing, deny nothing. This is the meaning of character... to invent, to mold, to elaborate, to influence... are the work of the writer. It is the writer's job to make the play interesting. It is the actor's job to make the performance truthful." ${ }^{22}$ I challenge this statement. Yes, it is the writer's job to create the story and it is most certainly the actor's job to deliver the story that is written; however, I do not agree that this can come without invention or elaboration. In order to act truthfully under imaginary circumstances, I have to know the text forward and backward. I have to know what has happened in-between and before each scene that I go onstage for. I have to allow my mind to go to places guided by past events in Kate's life, not necessarily my own personal life. This requires a trial and error process found in rehearsal and guided by invention within my imagination.

Journaling has proved to be a tried-and-true method of growth for actors. Writing down thoughts and moments of discovery in the rehearsal hall commits it further to memory, allowing it to stay there a bit longer than just hearing it or discussing briefly through the few hours of one day's rehearsal. Repetition also makes information stick in the mind. Free associative journaling ${ }^{23}$ combines the two. The work put into this writing examines and re-examines important parts of the text and personal identification with them. The actor's imagination is deeply flexed and cultivated, creating a specific point of view for the character.

The very first entry in the free associative writing journal is the conscious flow of my personal mind. The topic is always 'Personal Goals.' In true fashion for this style of writing, the timer is set to three to five minutes and the writing is continuous until the

\footnotetext{
22 Mamet, p. 41

${ }^{23}$ Free Associative Journaling is a specific journaling technique taught in class by Professor Jerry McGonigle as a supplement to the Meisner Technique.
} 
alarm goes off. No capitalization or punctuation is used and at no time does the writing stop. It is a flow of the conscious used to reveal the subconscious. Eventually, with this non-stop writing, the truth seated in a deep place rises to the surface. Free associative journaling brings out the purest honesty of the mind. 'Personal Goals' are defined for myself in a world separate from the play; now it is time to begin cultivating my mind with Kate's, developing a unique point of view.

To begin with, the script must be sifted through to find the 'Key Facts'. Such facts are defined by what is important to the character (people, places, things) and lines from the text when a personal, honest, truthful point of view is spoken ('Key Phrases'). The list of information I come up with must be the most provocative to me as the actor. This list of items gathered from the script becomes the map of the journal. Beginning with a Key Phrase, I write the text out at the top of my paper exactly as it is in the script. Once the timer is set, I reflect on the line for a few seconds. Then the writing commences for three minutes. I repeat this a few more times with a different Key Phrase each time on a new sheet of paper. This work with Key Phrases continues throughout the process of rehearsal and productions. It does not have to go in order, it does not have to have its own section in the journal, it only has to have its own sheet. Sometimes Key Phrases get revisited later in the process. Maybe something in rehearsal triggered a new thought, or journaling about another Key Phrase or character evoked a new perspective.

Starting with Key Phrases helps to get the creative juices flowing. We are not programmed to let our mind's thoughts flow freely and constantly. It can be a challenge to let that begin to happen. The key to attaching the actor's personal interpretation of the line and making it their own is that the writing must start from the perspective of the actor. As the following example demonstrates, I begin writing from my personal perspective letting the subconscious stream into the mind of Kate. This is how the free associative journaling process works in creation and cultivation of the character from the text given.

In Scene Three, Izzy has stepped forward to present her writing. Nerves cause her to apologize for her work, having only started it a few days ago. Leonard responds with the following: 
LEONARD. No it's good, if you have something on the page you should let people see it for Christ's sake. All this rewriting people do, it squeezes the guts out of everything. I read this story last week, couple weeks ago, it was so fucking lifeless, this person had clearly been rewriting this stupid thing for maybe ten years, there was just nothing left to it except a sort of desiccated corpse, it was ludicrous. If you're going to write, be a fucking man about it. Kerouac wrote On the Road in like a week or something.

KATE. Okay, I'm sorry but what did you say? Did you say you want us to "be a fucking man" about writing, and that we should write like Kerouac?

LEONARD. You should write like yourself.

KATE. Yes. Yes. I agree with that but if my "self" is a woman, I don't see why I then should write like a man.

LEONARD. If you're going to be some fucking feminist about it, that would be up to you, but I can't help you with that.

KATE. Feminist, I didn't say feminist, I said woman. Woman. What is wrong with being a woman and being a writer. ${ }^{24}$

This particular moment was an important part in the script for Kate. Her last line listed above has very little to do with feminism. Here is an example ${ }^{25}$ of the free associative journaling I used on this Key Phrase:

"Feminist, I didn't say feminist, I said woman. Woman. What is wrong with being a woman and being a writer."

I absolutely hate when people dismiss me and assume they know everything I'm talking about. Who the hell do you think you are that you can read my mind? And it's doubly infuriating when people lump you all together in one general wash of an idea, like you're a simpleton and lack complexity of any sort at all. It is so incredibly demeaning and gets my coals burning faster and more furiously than probably anything else I can think of. So then I have to correct them. I can't jus let it set. I will not be taken bluntly, at less than face value. Before you come in and disrespect me I demand that you give me an ounce of respect before jumping to this awful conclusion. And it's always the type of people who demand

\footnotetext{
24 Rebeck, p. 23-24.

25 The example was written without any punctuation or capitalization in the journal, as is noted previously in the text. It has been added in for ease of reading purposes.
} 
or expect every ounce of respect and awe you can muster up for them because they are higher up on the food chain. These are always the people who treat you like dog shit and I am a complicated woman damn it. I am not being a feminist - if I meant feminist I would have said it. I'm a fucking writer after all - I understand the value and accuracy in vocabulary. I meant woman because it is a far more encompassing word for who I am and what I bring to the table. So get fucked. Don't generalize me ever again. ${ }^{26}$

The conversation continues on in the script, but as demonstrated in the journal entry, there is a specificity and finality to Kate's perspective. The commanding stance she takes when speaking these lines is now clearly illuminated for myself as the performer. A clear point of view has been established and allows the line to never be delivered with any ambiguity.

Once the flow is started, I begin work on other characters, places, and objects in the script. I set aside several pages for each subject so I can reference all the work I've done in one easy location. Each character's name goes at the top of their own first page and underneath a list of all the lines in the play Kate speaks about them. The same sequence of events happens for places (i.e., the apartment, Bennington, Yaddo, MacDowell) and objects (i.e., Kate's Jane Austen story, Kate's Cubano story). The next step is very similar to the free form writing of the Key Phrases. The only difference is that there is no time limit. Writing can be as short as a few sentences or it can continue as long as several pages. The frequency with which I return to these subjects is far greater than my re-examination of the Key Phrases. I typically came back to each object every other day, if not every day.

The process of returning to each character to write a little bit about them worked like a puzzle. New thoughts or perspectives would surface about Kate's relationship to them, what she says about them, how she reacts to them. The script gave me these specifics, but how I perceived them was up to me. The challenge with Kate's relationship to Leonard and Martin was the deep complexity of her emotions for both of them, which lead to direct and finite interaction at the end of the script. Izzy and Douglas have a less defined relationship with Kate in the text, making this process of

26 Taylor, personal journal. 
development integral to making Kate real. A common theme that arose with Izzy is Kate's admiration of her power and ease of coercive application of this power. A clear opinion of her was created and a constantly fluxing admiration and disapproval lived in my creating of Kate.

Douglas, while having only slightly more interaction with Kate than Izzy did, was talked about far less by Kate. Kate only speaks a measly twenty-five lines to or about Douglas, but there is an undeniable growth in camaraderie between the two by the end of the show. She shows admiration for his work, frustration at his naivety stemming from being a male and valuing his opinion of her second work through all the interaction of text within the script. The following displays my discoveries made during the rehearsal process through the journaling. Each new paragraph is a new entry written at a different date:

I'm not jealous of Douglas - I'm excited by his stories of Yaddo and Macdowell, but not jealous. Bennington was a very similar experience for me. His wealth isn't anything to be envious of. He has 'connections'. I'm not sure how much he really has - it could be all talk. But I can tell he loves the craft, so that's worth respecting. His writing is very elegant and I do enjoy it. He's obviously got some success. I think he'll be one to push us along in talent/competition a bit in this seminar.

Ok, can I just say this about Douglas? He like doesn't give me any credit. Or not what I deserve - until he gets creamed. I mean, he's still all puppy-dog-eager when Izzy hands in her story the week following mine. Like he couldn't tell Leonard was an asshole after the way he treated my story? Douglass has got some phone in him... He's not loyal.

Douglas is a super nice guy. He may come off as insensitive and all-downing and pompous and egotistical, but I don't think he really is. He's really just trying to give us all helpful advice. Or he's genuinely curious about how to improve the writing. He doesn't deserve to be shit on by Leonard like he is. That moment when Leonard tells him to write for Hollywood and he replies, "But-l'm a fiction writer." Broke my heart. This is his ideal, his dream, his identity for the last 23-25 years. But Leonard is right. It is a hollow work. It's just hard to see someone's dream crumble in front of of them. He's like my brother at this point. Like and older brother, 
some one who I listed to and admired - without being afraid to call him out on his bullshit. To see him realizing his dreams will probably never come true is mobilizing. I just want to hold him.

Douglas doesn't really know how to take a joke. Well, I guess he takes it well. He doesn't sulk or pout or cry about it when I razz him, but he doesn't know how to dish it back. martin and I will take turns bantering and spitting it back into each others' faces. And it's fun! But it's fun teasing Douglas too - I always win. And I never have to be mean or hide a spiteful message in it. So it's always light and fun.

I think Douglas sold out. A bit. He gets called a whore and told he'll never be a really great fiction writer, but always through of as shallow, which would ruin anyone - f'ing mind games. But to just jump right into Hollywood? that's just really cheap. I mean, can he be anymore insecure? I know, I'm doing a ghost writing job-which some people take as a cop-out. But I'm not totally abandoning the craft of fiction. ${ }^{27}$

These journal entries span the entire length of the my process and are just a sample of the range of perspective I shuffle through. This journaling demonstrated that Douglas is not just another student in the seminar with Kate, but rather a complex relationship that affects Kate in her growth.

The places and objects have an extra component to the free associative journaling. I like to combine the image research with the writing. For instance, within the section of my journal about Kate's apartment, I would collect several images to help me define its openness, richness, view, layout, and would ultimately trigger the flow of my writing. Likewise, when writing about the Jane Austen inspired story, I found it helpful to use images of romance and elegance to identify with not only Austen's writing, but my own perspective on the woman's 'place' in society. The combination of free associative journaling and image research is an unparalleled freeing of the imagination.

The constant journaling filled its own eighty page book with thoughts, perspectives, and musings irrelevant to the audience who came to see Seminar. I did not create or invent anything new to the spectators, but I most certainly did create and

27 Taylor, personal journal. 
invent. I filled the gaps between scenes, I found some problems within the text that I had to fix to make sense to myself, I had to truly know Kate's world and point of view before I could do the story any justice in performance. This is where I challenge Mamet. In order to make the "performance truthful," 28 I must invent some things. Invention is precisely what the imagination does, and the actor cannot operate with the imagination.

\section{Meisner in the Rehearsal Hall}

Mentioned previously in the Text Analysis chapter, Meisner's technique of working readings did not benefit the learning of lines or creation of character for this show. The script's punctuation and phrasing was intentional and precise to give an orchestrated flow, much like Shakespeare's writing. Additionally, as in Shakespeare's text, the words of Seminar require and evoke action. There is not a lot of physical movement in the play, but there is a lot of action, all of which comes from the lines. The use of subtext is subtle in Rebeck's script. She gives the characters a freedom to speak what they really mean as their relationships grow stronger. This intimacy gives the speech more power; each line lands with distinct intent on the fellow actor(s) in the scene. In order to be effective, the actors must be honest and truthful with their intentions. This is where the practice of Sanford Meisner's teachings come into play.

The core definition of Meisner Technique is allowing a truthful, uncensored response to every stimulus presented. Oftentimes, especially in the beginning of this technique, it feels more like being bombarded with too much information as we allow ourselves to be hyper-aware. Time grants the receptors of the brain to relax and let the process permeate into habitual reactions. Once the actor has developed a sense of ease and trust with the work and their scene partners, reacting freely and unrestrained becomes a standard.

The cast of Seminar totals five actors. Two of them were fellow graduate students with whom I had been in the classroom with for two years already. The other two were seniors in the studio program with whom I was less familiar, but their willingness to trust the ensemble made it impossible to allow any inhibitions to take hold. This meant the

28 Mamet, p. 41 
learning process was rapid and discoveries were made quickly and continually by the director and the actors.

The first noteworthy discovery came a week into the rehearsal process. By this time, we had worked the text quite a bit, we were just starting to memorize, and it was our first evening in the space playing with free-form organic blocking. Having run the first half of the show a couple times that evening, Professor Blair's big impact of the night was to finish notes off with: "Be more selfish." Seems like a rather dangerous note to give to a group of actors. Realistically, it was a key point in the development of each character in the show. Nearly every time someone speaks in this show, it is in service of themselves. Every action is done to put self before others. Kate submits her story first to impress. She openly badmouths Izzy to try and pit others against her. She pretends she's going to leave the seminar in order to lure Leonard into her game. She writes the second story from a male perspective to fool Leonard. The action of this show is the five separate characters finding their separate ways through life. It was essential for me to tell the story solely from Kate's perspective. All of my blocking, speaking, and motives had to be done resolutely.

This tenacity in Kate is most apparent in scenes seven and eight. MidSeptember, a couple weeks before opening, I was becoming more and more frustrated with the build of this first scene. The argument between Leonard and Kate would build from her wanting to leave the seminar to him insulting her work and it was so terribly anticlimactic in rehearsal. The script builds to a moment where there is a finite beat, but defining that beat and mapping out how to get there was a troublesome blind spot. Finally, running it that particular evening, the frustration took hold and I stopped the scene, turned to Professor Blair, and asked him for help. Leading myself and the actor playing Leonard through provoking dialogue, we came to the conclusion that Kate knows exactly what she is doing. Kate is playing his game. She intends to beat him. She starts off the scene with a commitment to playing the hurt little girl who is going to give up. This is a delicate situation to approach as an actor. The timing must be precise and it must fluctuate each time the scene is played depending on perceptions between myself and the others on stage. This scene was one of the more challenging moments of focus for me as I had to be fully present in the scene, but more importantly, be fully 
present with Leonard to the point where the other three were not even on my radar. The text was precariously balanced with commitment to the frustration of being tossed aside alongside my first story and luring Leonard into reading my second story. Depending on the run, I would find myself falling to one side more than the other. It took a couple weeks of working with this discovery to really figure out how to ride the fence so both emotions could be committed to without sacrifice of my end goal. The balance could only be found in correlation to what Leonard was giving me. If we were not on the same page, the climax would not land.

One of the paramount challenges of this script is that it would be easy for the actor playing any role to play a stereotype, and up to this point in the play, Kate could be embodied as a spoiled, sensitive, sheltered, rich girl without any real injustice done to her. This moment in the play is where Kate's complexities begin to really surface. Scene seven does not illustrate her plan to the audience directly, but as events unfold and they are brought up to speed with the rest of the seminar students, a whole new depth to Kate is breached.

The end of scene seven brings about Leonard's praise for the story written by this unknown Cuban transvestite and a big victory for Kate. This win is a silent celebration. It is not until later in the evening in scene eight, after Leonard has left the group, that the classmates recognize her scheme. Even then, it is not commonly accepted as a triumph. Kate is still exceptionally vulnerable at this point. She shares her win with the others, rubbing in their faces her success and their complete disregard for her feelings these past weeks. Her text demands praise from the others, but burns them at the same time. Depending on the reactions I received from the actors on stage, I went through a wringer of emotions: triumph, pride, joy, defense, anger, frustration, denial, elation, malice, defeat, insecurity. The challenge to this moment was that Kate is doing most of the speaking. Usually, my reaction can come from others' lines landing on me. This scene, more than others, defined my reactions by watching my lines land on others.

The 'honest reaction' can be the quick summary of Meisner technique and the rawness of the process can be difficult to describe in writing. The goal was never to start out with basing our work in the Meisner technique, but as the process evolved, our 
small cast turned more and more to this approach. While this rawness and vulnerability can produce an extraordinary connection and truth on the stage amongst all of us, there is a very intellectual and studious part to the work that often times gets surpassed. This is the relationship of the actors to the director. An equality and trust must be built between the actors and director in order provide a safe place for growth and discovery. This environment was very clearly established in our rehearsals. Discussion flowed freely among the actors and director. Moments of rehearsal were spent in deep discussion of perception and realities of what we were doing or trying to do on the stage. There was a freedom established by the respect for one another and a respect for the work that allowed us to stop and question when we needed to. Not only could we ask for answers, but Professor Blair often answered in questions. During notes and discussions, there were moments when it was obvious Professor Blair wanted to tell the cast what we should be or needed to be doing, but he withheld these critiques. $\mathrm{He}$ rephrased his thoughts in terminology that let our own creative minds piece the path together. The teacher/student relationship in the Meisner technique is an empowering creative tool that goes unrecognized frequently. This perfect balance was found with ease in the rehearsal hall, allowing an ease to the creation.

\section{Problems with the Flow}

The struggle in defining Kate is not due to the aggregate growth she encompasses in the ninety minute show, but rather the fact that nearly all of it occurs offstage, in-between the scripted scenes. Rebeck has written-in a fantastic ramp through the course of the first eight scenes, launching Kate to retaliate against Leonard and re-brand her writing capabilities. It is at this point in the script when Kate is catapulted into an entirely new realm. Kate is found in Leonard's apartment after a three day sex-capade and with a severe deficiency of modesty. It is known that a larger amount of time has passed between scenes seven and eight than in any others throughout the show and it is known that something has obviously triggered Kate into sleeping with Leonard. Why or how are not even suggested. By this point, Kate has reached her full arc and attention is on Martin's crux of self-acceptance as a successful 
writer. The audience does not care why she has done this; the simple fact that it has happened is enough to satiate them.

The actuality of their copulation is far from enough for the actress portraying Kate. The use of Meisner throughout rehearsals has lead my interpretation of Kate to such a strong point of view of Leonard that this complete one-eighty turnaround is not warranted by the text alone. This is the first moment I had a problem with the text. Detailing every line that is said by any character throughout the play, I could not find a specific moment that triggered any desire for Leonard. In scene eight, as Leonard is having his 'blow-up' at Martin for whining about his writing, unveiling so much of the grief that materialized in his own life, there might be something there; but this is grabbing at straws. Having been deeply immersed in the text for the last several weeks, when the question came up, I was hesitant to blame the script. It had not let me down yet; could this have been a loophole in her writing?

Initially my reaction was to list what I was not given. Defining what was missing could only lead to what I needed. The last couple of weeks of rehearsal I was waiting for the inspiration to unfold. Having read the script several times before, my impression of Leonard was a worldly, dirty-sexy man. He should be a man that you hate because he comes off aggressive, but someone you want to be like or be with. Scene three exposes him as lust-driven as he comes onto Izzy for writing what Kate would define as smut. Douglas and Martin both have issues with him sleeping with Izzy because it is immoral, though every line they speak on the subject is dripping with jealousy. There is required of Leonard a sexual lure that Kate finds repulsive because it is cheap, until she rejects her uptight view of sex. Unfortunately, this did not come organically through the rehearsal process. The man cast as Leonard in this production, saying nothing against his talents or capabilities to act the role, was lacking in this mysterious sex appeal. This factor only made me rely on the text even more. I do not believe this was the intention of Rebeck. The text is not a stand-alone piece of work. The script is just the starting point in theatre, not the result.

Early September, after Professor Blair posed the question of when does Kate decided to sleep with Leonard, I wrote the following in my journal: 
"There is definitely a turning point in Scene 8, at the beginning when she tells him Luis is not coming-there is a moment of recognition when we see that Leonard has picked it up and pretty much knows that Kate wrote the story. He's a teacher and a stellar editor - he can find the similarities of the stories. And there's this moment of respect.

I've gained his [respect] at the end of the last scene when I see he likes 'Luis' work. Between the two scenes, I've lost my need for his public affirmation. I still respect/admire/crave his seal of approval, but I know I'm validated and certified as capable. The drive is no longer binding me.

Then at the end of Scene 8, Leonard delves into his big breakdown monologue. And it clicks for me. I realize it-him. This is not his prediction of Martin, but his life story. And I pity him. And respect him. And understand him. A tiny bit. Just enough to make me want to know more." 29

This did not give me a precise moment to indicate when I let my barriers down and decided my goal was to have sex with Leonard. I felt a little let down by the text, as though this was a problem with the script. However, it did give me something to go off. It gave me a starting point that lead me into further imaginative exploration via free associative journaling that helped to find this need and/or want.

Additionally, the 'moments' I had defined as meaningful were not always existent in delivery. The Leonard in this production did not always acknowledge me fully during the moment at the top of scene eight when I declared my decision to stay within the group, giving me nothing to 'Meisner' on some nights. It illuminates an issue I feel was never touched on: why does Leonard sleep with Kate? Just as it would be unjust to say Kate slept with Leonard for some shallow, insignificant reason, I feel lumping Leonard into the category of a man who will sleep with anyone is too flaccid for even him. Examining the process after the show, I feel my approach to this consensual act of sex was too individualized. I relied too heavily on my free associative journaling rather than the Meisner technique shared in the rehearsal hall.

29 Taylor, personal journal. 
Further discoveries of the richness of the text and character growth were made through discussions with the actor playing Douglas. He pointed out how often lessons are repeated through the script. For instance, Martin rails on the way Douglas talks: "idiotic, meaningless, self important observations about nothing, his words have nothing behind them. There's no music there's no joy there's no curiosity there's nothing." 30 Later in the show, after Douglas presents his story, Leonard basically says the same thing to him, calling him a 'whore' with his writing.

This thought illuminated Kate's growth for me. Her decision to sleep with Leonard was not a one hundred eighty degree turn, but a complete three hundred sixty. Most exciting for myself though, it was in the text:

"At the end of the show, I am relaxed. I'm living in realityI've come to terms with what the reality is. This new ghost writing job is good - it's not a cop-out, it's where l'm at. And who cares about sleeping with the instructor-it's reality! Why deny myself experiencing life for this conceived perception of right and wrong? I have to live life to write about it.

Leonard tells us all this in Scene 2, when he's tearing apart my story. "You got to understand that this is a totally irrelevant dream state you're hibernating in up here." He says this. By the end of the show, l've grown full circle. l've grasped the reality of life. Leonard has taught me."31

Rebeck did not leave the problem unaddressed, she wrote it incredibly realistically. Instead of approaching Kate as a problem to tackle, a story to figure out, she must be approached as a real student. Kate fiercely plows through life trying to 'win' and what she has learned slowly sneaks up on her and shapes her life. I had to 'learn' that there is a Kate within me and define how she ticks in order to unfold the story as the playwright intended.

\footnotetext{
30 Rebeck, p. 13

31 Taylor, personal journal.
} 


\section{Challenges of Tech}

Theresa Rebeck does genius things with gender issues in this script through her artistry. She also does some rather challenging things to the actors who perform this script. Everything discussed prior to this point in the rehearsal process has dealt with the psychologically taxing demands upon the actor's mental reserves. Arrival at tech rehearsals brought forward a whole new set of mental struggles for the actor. A minimalist need for scenery plus the passage of time between scenes means there will have to be costume changes and prop changes during each blackout. Eight of the nine scenes take place in Kate's apartment, meaning she is usually present for the majority of each scene. The time allowed for myself to mentally and physically adjust was usually a handful of seconds.

The first night of tech our company was short a stage manager, thanks to bronchitis. Additionally, as is standard at West Virginia University, the first night of tech was done without costumes. The absence of the costume crew and our stage manager meant specific costume changes between scenes could not be traced accurately. The work that was done included bringing on new props; clearing the stage of no longer needed props; paper scattering; and drink shifting, removal, or refilling-all involving a choreographed handoff to or from a crew member. It was tedious and frustrating at times. Everyone had suggestions, actors and crew alike. It took Professor Blair leading the charge before any efficient progress was made. However, continuity issues would be noticed later in the play's shifts, changing previous choreographed tech work. It was not an impossible or even a terribly difficult task, but it was time consuming and proved to be one of the most mentally taxing scene-shifting experiences I have had to endure as an actor.

Day two brought costumes. Nearly everything we had just learned had to be modified. Actors could no longer be as much help since blouses, pants, and shoes were being changed. Furthermore, a majority of costume changes had to take place on the stage for time's sake. Costume crew members were now added to the choreography and routes were changed so wine glasses did not clink into velcro sweaters being torn off and paper scatterers did not plow into wine bottle re-fillers. While it was an organized 
chaos, the sounds of stage hands whirring by as I was trying to button up my sweater in total darkness felt like utter pandemonium.

First dress rehearsal was the day I first noticed fatigue and other signs of my illness creeping up on me, causing fogginess of mind. Often, after I handed off a wine glass and changed my shirt, I had a split second before the lights came up to try and remember what the next scene was about. This usually involved me praying my line was not the first in the scene. Technical rehearsals are there for a reason, though. I simply had to trust that with a little bit of time, all of this bedlam would become second nature.

\section{The Voiceless Actor}

Rebeck's script is not terribly demanding on the voice as far as intensity or dexterity goes. It is demanding on the three larger roles (Leonard, Martin, and Kate) as it gives them little rest through the course of the ninety minute show. The quantity of spoken text for Kate is not taxing by itself, but with an outside illness affecting the larynx and pharynx already, there is no break provided. This challenge presented itself during tech weekend and hung around through the first week of the show. While it digressed into the second week of the run, it threatened to come back in full force.

The first sign of trouble became apparent after first dress. Projection was a struggle for all of the actors in this production as it is a terribly intimate setting with a flow and rhythm to the conversation. Radiating the sound throughout the entirety of the theatre became difficult as I faced symptoms of the common cold: sore throat and difficulty breathing. The following Monday was dark, allowing me to use the free time for both vocal and physical rest to let this illness leave my system.

Monday, however, brought a complete loss of voice. The doctor diagnosed acute laryngitis and upper respiratory infection giving me the damning news that it would just have to pass on its own. Due to the circumstances of having performances every night for the next two weeks, she gave me a Z-Pack to maybe speed up the recovery, and a five day supply of steroids to make phonation possible. Tuesday I cancelled the classes I taught and stayed in bed all day. Normally, a loss of voice is temporary, having never lasted more than two or three days for me in the past. So while panic mode had not yet 
struck, it was hovering above me as preview was in two days and there was no understudy. Suddenly my voice loss did not only hinder my performance, but four others' as well.

The preemptory measures taken to alleviate the stress on my vocal folds were extensive: vocal rest, physical rest, steaming, eucalyptus oil, slippery elm throat lozenges, hot tea and water, substituting the juice 'wine' on stage for water. None of this could prevent Tuesday evening's dress rehearsal carrying one of the single most frightening experiences of my life. Making it up to scene six, I was pushing my voice without absolutely exhausting it. Professor Blair stopped the show at the top of this scene. I had begun to mark through the text and he was concerned it was an involuntary choice that was caused by overexertion. The decision to continue was made, for I only had this scene left before a significant decrease in spoken text for Kate. The scene continued. I was going through the motions on pure adrenaline, trying to pace myself to make it to the next scene shift. Kate's big moment in this scene is her reveal that she wrote the Cubano Transvestite piece, unleashing the news with a spin, throwing papers into the air. I was fading fast through the first few minutes of the scene, but thought, "If I can just make it through this monologue, just throwing these papers will give me that last kick of energy!" Alas, it did not. Instead, I threw the papers, stopped, turned around and whispered that I could not go on. It was frightening. The horrible pause where no one said anything; staring back at the faculty members and fellow students who had designed and were running the show; the split-second fear in the casts' eyes as veiled uncertainty passed through them. It was a minute display of the fear in myself echoing through twenty other people's minds.

The following day was our final dress rehearsal before preview. The decision to go through with it was left in my hands. Sleeping on it, to wait and see if my body would heal, but mostly because that was all I could do, I felt no better by noon. Coming to campus early in hopes of sitting through classes to observe, I received Reiki healing from Professor Laura Hitt. The science and procedure of this Eastern world medicine is foreign to me, but the healing energy left with me was at a comprehension beyond words. This healing illuminated tensions that had crept into my body the last few days that I was unaware of. It gave a warming energy to me, and most importantly, it gave me 
a release. The responsibility to push myself was lifted and the need only to rest and let my body do what it could took over. Sitting in the silence after the Reiki session, my cellphone jarred me out of my meditative state: it was a text message from our stage manager announcing final dress rehearsal had been canceled. The responsibility was taken out of my hands, alleviating the last bit of pressure. All I had to focus on now was not letting the droning sensation of worry consume me.

The following day was much better. The medication was finally kicking in and the adrenaline of performing in front of an audience was driving me. Two new challenges were arising. First, the steroids were making me a bit queasy. Unfortunately, this never happened at predictable times (i.e., thirty minutes after taking it), so it could hit during warm-ups, pre-show, or even mid-performance. There was now way to fix this; it was simply a hinderance to be dealt with. The second major issue was the warm-up. There was no way full vocal range could be accessed and the risk of using up the strength of the vocal folds in the short warm-up pre-show was too great. However, simply foregoing any warm-up was out of the question.

This dark, terrifying moment in my performance career brought forth a startling discovery of the importance of a physical warm-up. Stretching had always been a starting point of my personal pre-show warm-ups, but only in short stints. My recent practice of yoga had illuminated for me the connection of body and breath in a way that made perfect sense. The practice of doing multiple Surya Namaskara (Sun Salutations) connected the flow of blood throughout my body, increasing my heart rate and energy while also stretching of a large amount of my body's muscles. The application of Ujjayi breath (a slight restriction in the throat allowing a gentle sound to be made without vocalization) produced a warm air flow through my breathing apparatus. This meant I could work my vocal folds to a level ready to produce a range of sound without fatiguing them. Not only did it prepare me physically, but it cleared my mind and cleansed it of any doubt or worry that would creep in if I thought too much of the task at hand. Through the course of the show, up until the last couple of performances, I had to rely on a non-vocal warm-up and this yoga practice was what prepared me fully for each night. 
Preview went well and Professor Hitt commented that the use of my voice was incredibly effective and the illness was not even remotely showing through my performance. The vocal rest and use of a yoga-based warm-up allowed for successful vocal delivery through the opening weekend; however, the struggle continued. I was feeling better until the weekend. Upon returning to the doctor the following Tuesday out of fear from feeling the same starting symptoms on Monday, there was nothing to be done. A refill of the steroid prescription would not be given for the last six days. They would, however, give me a rush referral to an otolaryngologist. The following day I saw a specialist for a scope of my vocal folds. This procedure was singlehandedly the most uncomfortable feeling (and most exciting), as my vocal folds were seen by another human being for the first time. The irritation in my vocal folds was pinpointed to the arytenoid cartilage located on the back of the vocal folds, responsible for their movement (see fig. 12). But the cause was undeterminable, or insignificant. Vocal rest was prescribed. Starting week two of the run, this was impossible. Simply continuing the mollycoddling of my voice was all that could be done. Pain when swallowing (the watered down juice 'wine'

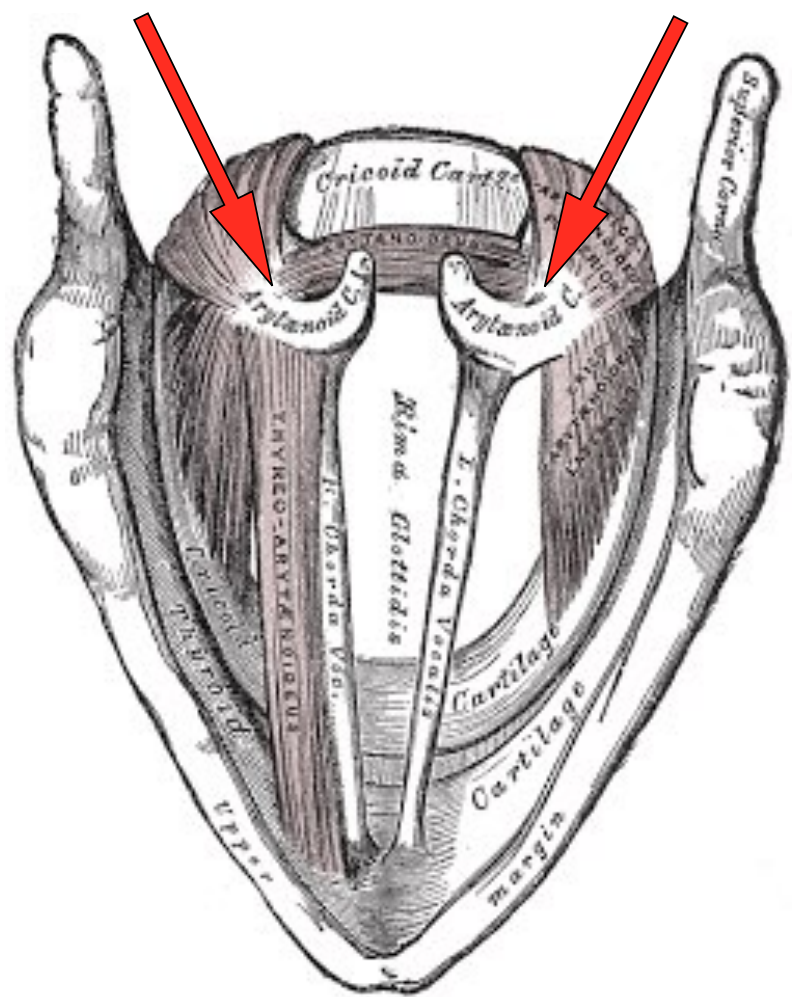

Fig. 12 View of the Larynx from above, showing the connection of the Arytenoid Cart. to the back of the vocal folds. became my nemesis during this show) and pain when talking gradually diminished through the second week run. The newly found yoga warm-up proved to be reliant and a valid exercise to prep the body and voice for the stage. 


\section{Relationship with the Audience}

The performance of this show was electric. All of the worries of vocally intimate scenes not reaching to the back of the theatre or the fear that there was not enough physical action to keep the audience engaged dissolved from the night of preview and through all nine performances. The real consternation of preview was making it through the performance with an audience using my tenuous voice, and as previously mentioned, that was executed with a proficiency. Certainly, there were little errors of running the show with all the technical elements and 'choreography'-that can only be expected when one and half dress rehearsals are cancelled.

Opening night was everything I could have hoped for it to be. Time was taken for a full and methodical warm-up, energy was flowing through the cast and production team, the audience was hanging on every word spoken, and the actors were on fire. Unfortunately, this did not continue through the second run of the show. Whether it was due to complacency, a lack of connection among the cast, or that the audience was not as attentive Friday night, something derailed the Seminar train. This second-night problem was in no way noticeable to the audience, but in such an intimate play, the tiniest things can disjoint the whole flow for the actor: not getting a beer bottle struck from the stage in-between scenes, a sweater not getting fully buttoned up before lights come up, stumbling over a line, not getting a reaction expected from a cast mate or not getting the full glass of wine drunk in order to fill it up on cue. All of these minute, seemingly insignificant details do not appear to matter much. Recalling the use of Meisner Technique in the rehearsal hall, the amount of focus on letting events, text, actions effect the actor allows for hyper-sensitivity. Use of this technique in rehearsal most certainly means use of this technique on the stage. The total commitment made by actors in such a process means a great deal of sensitivity to flow, procedure, and reactions. In my mind, it was a train-wreck. The audience still left buzzing about the show, though.

The use of Meisner Technique in the performance adds another layer of sensation to the actors: the sensitivity to audience reaction. This new layer is overwhelming and invigorating. Moments through the run of the show brought about 
intoxication of certain actors at specific moments, leading to over-energizing to get that extra bit of reaction. Sometimes the hold of the audience in the actors' relationships was gripping in an inhibiting way. One such moment I personally experienced was in the final scene in which Kate entered wearing nothing but panties and an open button-down shirt. This was by no means the full-frontal flashing the fellow actress portraying Izzy had to do, but it was just as daunting, if not more inhibiting. Flashing meant knowing parts of the audience were going to see breasts. My lack of comfort came from the fact that the audience might see them. In other words, there was still a hope to keep myself covered. Body image is something I have never been terribly comfortable with; add peers to the jury and it makes the judgment all the more terrible. Additionally, I had students in the audience. The last two years in the masters program have given me the experience of teaching intimate acting classes for non-majors, lectures of a couple hundred students, and small classes for majors. I found myself wondering which scenario would be better: hundreds of students who I would not necessarily have to look in the face next class seeing me naked, or twenty who I would have to teach one-onone the following morning? Eventually, the trepidation wore thin as the reality of it happening surfaced. There was nothing I could do with it but be comfortable. Kate was clearly not ill-at-ease during this moment of her life.

The remainder of the performances continued to go well and continued to be unique each night. The reactions from the audiences were always bold and always determined the performance of the actors. Regardless of size, ticket sales ranging from full capacity to less than a third of the house, they were engaged with us. People left talking about the show. People would see me days later and tell me how much they have been thinking about Seminar and how they got into debates with their friends about it. In talk-back discussions with peers, vehement debates of motives of the characters broke out as perceptions from audience members collided with other audience members and even cast members. Is this not the goal of theater? To make a change, to prompt initiative in the observers? This occurred here. Art was made via communication between the performers and the audience and a more beautiful outcome could not have been asked for. 


\section{EVALUATION}

Seminar was received with wide-swept success at West Virginia University. Daring and unapologetically bold in content, it pushed the borderlines of appropriateness and fascinated the student population with its blatant honesty. It is difficult to imagine such success when it ran for less than six months on Broadway with a month of previews and received a review from New York Times theatre critic Ben Brantley that was not entirely gracious of Rebeck's writing. The difference is all in the audience. Here, somewhat generalized stereotypes of personalities are accepted and solidified in the minds of the audience because they are of this age and can directly relate. The hardships, lies, pain, honesty, and process of finding oneself are directly relatable and pertinent to the vast majority of our college student audience. Acknowledging the success in this specific location, I also concede to the flaws within the script I was blind to see in the beginning and throughout the process.

The text demanded a true reality of each character, but it failed to establish a thorough or solid foundation for such work. Myself and the other actors creating on the stage poured a wealth of self discovery into our characters in order to fully flesh them out. This offering left me vulnerable and susceptible to any negative critique of the writing and portrayal of Kate. It has taken time away from the performance for me to fully comprehend the complexity of this production. Seminar is not deplorable by any means, but it did have its faults. To be able to admit this demonstrates a growth in my comprehension of theatrical writing, something I had not fully understood or appreciated, but rather revered with a detached piety. Trusting the work is a must for an actor, but questioning it can only deepen the quality.

Trusting the director's vision and evaluation is an even greater undertaking through the process of bringing the script to the stage. The necessity to feel safe in the growth and creation of character is not something to be taken lightly. Professor Blair established such an environment by instilling his trust in us, the performers, only reigning in the work when necessary. The reserved guidance given by the director allowed room for trial and error in the rehearsal hall with no consequence. Via participation and observation of this process, I developed a healthy respect for the openness and faith directors and actors put in one another. 
Kate came at the right moment in my life. Education has consumed a vast majority of my life thus far and a clear line between good and bad or right and wrong has always been dictated by grades. There has always been a fear in my creative process of getting it 'wrong' in front of others. I have always come prepared to the best of my capabilities, doing 'good' work, and never quite feeling like I have done something extraordinary. Additionally, a respect for teachers has kept me from questioning what I was taught. Kate's growth breaks through this barrier in her life in the text. The amount of my personal being that I used through the free associative journaling and image research meant a certain finite change within myself. Through her defiance, Kate tries to break down dismissive judgements of Leonard and her peers, but in reality breaks through the barriers she has put up herself. In the same way, I liberated myself by stubbornly defying objection to my work. I was steeped in a safe, trusting environment, permeated with honest reactions tailored by the Meisner technique and I still managed to resist the notion of not having the 'right' answers in the rehearsal hall. As rehearsals progressed, I found less and less to defy and eventually this struggle was thwarted as there was nothing to feed it. I had good days and bad days; helpful contributions and not-so genius commentary; powerful, transcendent connections to cast members and moments where I left them needing; brief moments of unmitigated conviction in my delivery and tedious moments of grasping at straws-but it all worked out.

Just as the characters in the play break through their stereotypes in the last few scenes, defining their individual talents, wants, and needs, I too broke out of the habit of generalization. Determining the needs of Kate, I clarified and became comfortable with my particular wants and needs as a person and a performer. There came about a defined process of character development that has been in the works the last couple of years of my master's training during this production of Seminar. It is with deep gratitude that Kate has taught me what Chekhov meant when he said to "stubbornly, frantically follow your own way..." 


\section{BIBLIOGRAPHY}

\section{Website Articles}

"A Short History of City Lights." Web. 22 June. 2014.

"Academics/Areas of Study/Literature." Web. 5 August. 2014.

Brantley, Ben. "Shredding Egos, One Semicolon at a Time." Theatre Review. The New York times 2011. Web. January 222015.

"History." Web. 12 August. 2014.

"Salman Rushdie." Bio. A\&E Television Networks 2015. Web. 8 August. 2014.

"Seminar on Broadway." Playbill. Web. 22 January. 2015.

"The MacDowell Colony." Web. 12 August. 2014.

\section{Books and Scripts}

Austen, Jane, Joanna Strange, and Derek Strange. Pride and Prejudice. London: Penguin, 1992. Print.

Austen, Jane, and Rosalind Ballaster. Sense and Sensibility. London: Penguin, 2003. Print.

Fraser, Tara. Total Yoga: A Step-by-Step Guide to Yoga at Home for Everybody. London: Watkins Publishing, 2007. Print.

Kerouac, Jack. The Dharma Bums. New York: Penguin, 2006. Print.

Kerouac, Jack. On the Road. New York: Viking, 1997. Print.

Kerouac, Jack, and Allen Ginsberg. Visions of Cody. Penguin, 1993. Print.

Linklater, Kristin. Freeing the Natural Voice: Imagery and Art in the Practice of Voice and Language. Hollywood: Drama Publisher (an imprint of Quite Specific Media Group Ltd.), 2006. Print.

Mamet, David. True and False: Heresy and Common Sense for the Actor. New York: Vintage, 1999. Print.

Meisner, Sanford, and Dennis Longwell. Sanford Meisner on Acting. New York: Vintage, 1987. Print.

Mullan, John. How Novels Work. Oxford: Oxford University Press, 2006. Print.

Rebeck, Theresa. Seminar: A Comedy. USA: Samuel French, 2012. Print.

Rodenburg, Patsy. The Actor Speaks: Voice and the Performer. United States: Palgrave Macmillan, 2002. Print.

Rushdie, Salman. Fury: A Novel. New York: Random House, 2001. Print.

Rushdie, Salman. The Moor's Last Sigh. Thorndike, ME: G.K. Hall \& Co, 1996. Print 
Sher, Antony. Year of the King: An Actor's Diary and Sketchbook. Compton Plains, New Jersey: Limelight Editions, 2006. Print.

Silverberg, Larry. The Sanford Meisner Approach Workbook Four, Playing the Part. Hanover, NH: Smith and Kraus, 2000. Print.

Warren, Renee. "Jane Austen Biography." 2014. Web. September 102014.

\section{Personal Documentation \& Communication}

McGonigle, Jerry, and Brianne Taylor. "Meisner Technique Graduate Acting Class." Notes and journal from classroom instruction on the Sanford Meisner technique ed2013. Print.

Taylor, Brianne. "Seminar Journal: Creation of Kate." Personal journal documenting research, free associate journaling, and process of rehearsals and performances. 2014. Print 